\title{
Secular and orbital-scale variability of equatorial Indian Ocean summer monsoon winds during the late Miocene
}

\author{
Clara T. Bolton ${ }^{1}$, Emmeline Gray ${ }^{1,2}$, Wolfgang Kuhnt ${ }^{3}$, Ann Holbourn ${ }^{3}$, Julia Lübbers ${ }^{3}$, Katharine
}

5 Grant $^{4}$, Kazuyo Tachikawa ${ }^{1}$, Gianluca Marino ${ }^{4,5}$, Eelco J. Rohling ${ }^{4,6}$, Anta-Clarisse Sarr ${ }^{1}$, Nils Andersen $^{7}$

1. Aix Marseille Univ, CNRS, IRD, INRAE, Coll France, CEREGE, Aix-en-Provence, France

2. Now at: School of Environment, Earth and Ecosystem Sciences, The Open University, Milton Keynes, UK

3. Institute of Geosciences, University of Kiel, D-24118 Kiel, Germany

4. Research School of Earth Sciences, Australian National University, Canberra ACT 2601, Australia

5. Centro de Investigación Mariña, Universidade de Vigo, GEOMA, Palaeoclimatology Lab, Vigo, 36310, Spain

6. Ocean and Earth Science, University of Southampton, Southampton SO14 3ZH, UK

7. Leibniz Laboratory for Radiometric Dating and Stable Isotope Research, University of Kiel, D-24118 Kiel, Germany

Correspondence to: Clara T. bolton (bolton@cerege.fr)

\begin{abstract}
In the modern northern Indian Ocean, biological productivity is intimately linked to near-surface oceanographic dynamics forced by the South Asian, or Indian, monsoon. In the late Pleistocene,

20 this strong seasonal signal is transferred to the sedimentary record as strong variance in the precession band (19-23 kyr) because precession dominates low-latitude insolation variations and drives seasonal contrast in oceanographic conditions. In addition, internal climate system feedbacks (e.g. ice-sheet albedo, carbon cycle, topography) play a key role in monsoon variability. Little is known about orbital-scale variability of the monsoon in the pre-Pleistocene, when atmospheric $\mathrm{CO}_{2}$

25 levels and global temperatures were higher. In addition, many questions remain open regarding the timing of the initiation and intensification of the South Asian monsoon during the Miocene, an interval of significant global climate change that culminated in bipolar glaciation. Here, we present new high-resolution $(<1 \mathrm{kyr}$ ) records of export productivity and sediment accumulation from International Ocean Discovery Program Site U1443 in the southernmost Bay of Bengal spanning the late Miocene and earliest Pliocene (9 to 5 million years ago). Underpinned by a new orbitallytuned benthic isotope stratigraphy, we use X-Ray Fluorescence-derived biogenic barium variations to discern productivity trends and rhythms. Our data show strong eccentricity-modulated precession-band productivity variations throughout the late Miocene, interpreted to reflect insolation forcing of summer monsoon wind strength in the equatorial Indian Ocean. On long timescales, our data support the interpretation that South Asian monsoon winds were already established by $9 \mathrm{Ma}$, with no apparent intensification over the late Miocene.
\end{abstract}




\section{Introduction}

The Asian monsoon is a major hydrological phenomenon driven by the pressure gradients created by asymmetric heating between the equatorial Indian and western Pacific Oceans and the IndoAsian landmass, creating strong seasonally-reversing winds and ocean currents and heavy boreal summer precipitation over the Bay of Bengal and Indian subcontinent (Webster, 1987a, b; Schott and Mccreary Jr, 2001; Gadgil, 2003; Schott et al., 2009). Surface winds over the northern Indian Ocean (Arabian Sea and Bay of Bengal) and South China Sea are strong indicators of the strength of the South Asian and East Asian monsoon subsystems, respectively, and precipitation amount and seasonality can also be diagnostic of monsoon strength (e.g., Webster and Yang, 1992; Goswami et al., 1999). Thus, past monsoon dynamics can be reconstructed using wind, runoff, and precipitation indicators recorded in marine sediments from these core convective regions. The Asian monsoon is known to have varied substantially over short (interannual to suborbital) and long (orbital to geological) timescales in response to forcing factors both external and internal to Earth's climate system (e.g., Wang et al., 2005; Clemens and Prell, 2003; Farnsworth et al., 2019; Kathayat et al., 2016).

There is great uncertainty surrounding the timing of Asian monsoon initiation and intensification, and the degree of coupling between regional monsoon subsystems. Discrepancies in part stems from the fact that records come from the South Asian or East Asian monsoon subsystems, which are sensitive to different aspects of regional topography (Molnar et al., 2010; Clift et al., 2008; Clift and Webb, 2019; Boos and Kuang, 2010; Acosta and Huber, 2020; Sarr et al., in review). Further, differences in monsoon expression occur even within the core convective region of the South Asian monsoon (e.g., dominance of summer monsoon winds in the southern Bay of Bengal versus monsoonal rainfall/runoff in the northern and eastern parts). Meanwhile, proxies generally record singular aspects of monsoonal climate that are not necessarily coupled on all timescales (e.g., winter versus summer monsoon, wind intensity versus precipitation amount or seasonality). Evidence for strong monsoonal climates (i.e., with strong seasonality of precipitation) exists across Asia during

65 the Paleogene (Spicer et al., 2017; Licht et al., 2014), yet many terrestrial records from southeast Asia suggest an onset of the monsoon near the Oligocene-Miocene boundary ( 24-22 Ma) (Guo et al., 2002; Sun and Wang, 2005; Wang et al., 2005). Marine records of drift sedimentation near the Maldives archipelago as well as upwelling and oxygenation indicators from the Arabian Sea, both influenced by wind and surface ocean circulation, suggest an onset of strong seasonally-reversing South Asian (monsoon) winds and Arabian Sea upwelling during the late middle Miocene ( 13-10 
Ma) (Zhuang et al., 2017; Gupta et al., 2015; Betzler et al., 2016; Betzler et al., 2018; Bialik et al., 2020; Nigrini, 1991).

In contrast, a time interval in which records from different regions and proxies converge somewhat is the late Miocene. Magnetic records from the Chinese Loess Plateau are interpreted to show a long-term intensification of the East Asian summer monsoon (EASM) from 8.2-2.6 Ma (Ao et al., 2016). A late Miocene strengthening of Asian winter monsoons is inferred from South China Sea (Holbourn et al., 2018; Jia et al., 2003) and Andaman Sea (Lee et al., 2020) records. In the Arabian Sea, an intensification of upwelling and productivity at $\sim 8 \mathrm{Ma}$ is interpreted to reflect a strengthening of the South Asian summer monsoon (SASM) (Kroon et al., 1991; Singh and Gupta, 2014; Gupta et al., 2004), although other studies find evidence contrary to this (Tripathi et al., 2017; Huang et al., 2007). Proposed monsoon intensifications during the late Miocene roughly coincide with strong global cooling (Herbert et al., 2016), and a number of studies have implicated cooling and the ramp-up of Antarctic glaciation in monsoon strengthening (Ao et al., 2016; Holbourn et al.,

85 2018; Gupta et al., 2004). Until now, a lack of continuous, well-preserved marine sequences from the South Asian monsoon region has stalled our understanding of its complex evolution during the Miocene.

The SASM is thought to have varied strongly on orbital timescales because monsoon strength responds, both directly and via internal feedback mechanisms, to insolation forcing. Model simulations predict a stronger South Asian monsoon during summer insolation maxima at both precession minima and (to a lesser degree) obliquity maxima (Bosmans et al., 2018; Prell and Kutzbach, 1992, 1987; Kutzbach, 1981; Jalihal et al., 2019; Tabor et al., 2018). Precession is the dominant control on insolation and its seasonal distribution near the equator, and proxy-based Pleistocene SASM records show strong precession-band (19-23 kyr) variability (Kathayat et al., 2016; Prell and Kutzbach, 1987; Clemens et al., 1991; Clemens et al., 2021; Zhisheng et al., 2011; Bolton et al., 2013; Caley et al., 2011; Gebregiorgis et al., 2018; Wang et al., 2005; Clemens and Prell, 1990; Rostek et al., 1997). The influence of global boundary conditions related to ice volume and greenhouse gas concentrations on SASM winds and precipitation/runoff is also demonstrated

100 by strong obliquity- and eccentricity-band variance in Plio-Pleistocene records (e.g., Clemens and Prell, 2003; Gebregiorgis et al., 2018; Clemens et al., 2021; An et al., 2011). Our current knowledge of orbital-resolution past productivity fluctuations in the South Asian monsoon region and their relationship with local (insolation) or remote (global ice volume, greenhouse gases) forcing mechanisms comes almost entirely from Pleistocene Arabian Sea sedimentary records (Clemens 
and Prell, 2003; Caley et al., 2011; Singh et al., 2011; Shimmield and Mowbray, 1991; Rogalla and Andruleit, 2005; Clemens et al., 1991; Ziegler et al., 2010). These records suggest that summer monsoon proxies significantly lag northern hemisphere summer insolation maxima in the precession and obliquity bands due to climate feedbacks. Orbital control on past SASM strength in the pre-Pleistocene, when boundary conditions were different, has so far only been investigated in the Andaman Sea over the latest Miocene-early Pliocene, where seawater oxygen isotope data suggest high-amplitude precession and obliquity forcing of monsoon rainfall with significant phase lags (Jöhnck et al., 2020).

In this paper, we investigate sediment accumulation and export productivity dynamics at millennial

115 resolution in late Miocene sediments from southern Bay of Bengal (BOB) International Ocean Discovery Program (IODP) Site U1443 ( $5^{\circ} \mathrm{N}, 90^{\circ} \mathrm{E}$, Fig. 1). The late Miocene (11.6-5.3 Ma) is an interval of major global climate change, with long-term cooling between 7.5 and $5.5 \mathrm{Ma}$ (Herbert et al., 2016) culminating in major high-latitude cooling events (Holbourn et al., 2018), and important carbon cycle shifts recorded in the marine and terrestrial realms potentially linked to atmospheric $\mathrm{CO}_{2}$ decline (Tauxe and Feakins, 2020; Steinthorsdottir et al., 2020). The region of Site U1443 is strongly influenced by seasonally reversing monsoon winds today, and primary productivity is tightly coupled to the annual monsoon cycle (Fig. 1a-b, Fig. 2). During the SASM, strong moisture-laden winds blow inland, driving surface circulation changes and increased mixed layer depth (Fig. 1a-b) (Webster, 1987a, b; Schott and Mccreary Jr, 2001; Gadgil, 2003; Schott et al., 2009). Strong Ekman pumping mixes nutrients into the surface layer during the South Asian summer monsoon and, to a lesser extent, the winter monsoon, stimulating biological productivity

(Fig. 2) (Lévy et al., 2007; Mccreary et al., 2009; Koné et al., 2009; Behrenfeld et al., 2005; Longhurst, 1995). This strong seasonal signal is transferred to the sedimentary record in the form of strong variance at orbital periods because insolation variations drive seasonal contrast. In this paper,

130 we generate a new orbitally tuned age model based on benthic foraminiferal stable isotopes spanning $\sim 9$ to $5 \mathrm{Ma}$. Core-scanning X-Ray Fluorescence (XRF) data are then used to reconstruct bulk, carbonate, and biogenic barium content and mass accumulation rates (MARs), shedding light on secular and orbital-scale export productivity and sedimentation changes over the late Miocene.

\section{Background}

In the modern southern BOB in waters overlying Site U1443, both primary and export productivity are strongly controlled by seasonally reversing winds associated with the South Asian monsoon. 
Figure 2 shows the annual cycle of wind stress, mixed layer depth (MLD), net primary productivity (NPP), and biogenic particle export based on recent oceanographic, satellite, and sediment trap data (see methods for details). In boreal summer (JJA) strong southwest winds mix the upper water column, deepening the MLD to $\sim 60 \mathrm{~m}$ and entraining nutrients into the photic zone, leading to enhanced primary productivity and biogenic particle export (with a lag of $\sim 3-4$ weeks) (Fig. 1a-b, Fig. 2). During boreal winter, northeast winds deepen the MLD to a lesser extent, resulting in a second smaller peak in productivity during the winter monsoon (DJF) (Fig. 2). During the intermonsoon seasons, lowest wind stress is recorded leading to a shallow MLD, higher Sea Surface Temperatures (SSTs), and a more stratified upper water column, resulting in increased oligotrophy and reduced biological productivity. The biannual productivity maxima observed in the surface ocean above Site U1443 is characteristic of monsoon-dominated tropical regions (Longhurst, 1995; Lévy et al., 2007). Sediment trap data suggest that primary productivity is the dominant control on organic carbon export at a location west of the northern end of the Ninetyeast Ridge (SBBT site; $5^{\circ} \mathrm{N}, 87^{\circ} \mathrm{E}$, Fig. 1c). However, lithogenic mineral ballasting at this location is not negligible (average $\sim 13 \%$ and 15\% lithogenic particles in shallow and deep traps respectively) (Rixen et al., 2019; Unger et al., 2003) and could in part explain the bias towards the late summer peak seen in biogenic fluxes compared to NPP, as maximum concentrations of lithogenic particles at SBBT occur during the summer monsoon. While wind forcing is identified as the dominant factor controlling biogenic particle fluxes at the SBBT site, advection of nutrient- and chlorophyll-rich waters originating from the eastern Arabian Sea via the Southwest Monsoon Current (SMC) may further contribute to the summer productivity peak in this region (Unger et al., 2003). During the summer monsoon, the relatively salty and nutrient-rich SMC flows eastwards south of Sri Lanka then turns northwards into the BOB (Fig. 1c) (Schott et al., 2009; Jensen, 2003). The SMC and associated eddies have been shown to increase chlorophyll concentrations and average phytoplankton size along their paths as far east as $88-90^{\circ} \mathrm{E}$, with the current's influence generally restricted to north of $6^{\circ} \mathrm{N}$ at this longitude (Jyothibabu et al., 2015; Vinayachandran et al., 2004; Webber et al., 2018). While river runoff and resultant salinity stratification during the summer monsoon supress primary productivity further north in the BOB (Prasanna Kumar et al., 2002), seasonal surface salinity variations are very small $(<0.2 \mathrm{psu})$ at $5^{\circ} \mathrm{N}$ (Zweng et al., 2013). Accordingly, monsoon impacts on nutrients and productivity in our study area are limited to those driven by surface currents and wind mixing, and biogenic export fluxes during the SASM are similar (Particulate organic carbon, $\mathrm{POC}$ ) or higher $\left(\mathrm{CaCO}_{3}\right.$ and biogenic $\left.\mathrm{SiO}_{2}\right)$ than at sites further 170 north in the BOB (Unger et al., 2003). Thus, modern data give us confidence that export productivity at our site is likely a reflection of South Asian (primarily summer) monsoon wind 
strength, via its control on MLD and nutrient entrainment into the mixed layer as well as on surface ocean currents.

\section{Materials \& Methods}

\subsection{Site and sampling}

Samples used in this study are from Site U1443 (Latitude $5^{\circ} 23 \mathrm{~N}$, Longitude $90^{\circ} 21 \mathrm{E}$, water depth $2935 \mathrm{~m}$ ), drilled during IODP Expedition 353 on the crest of Ninetyeast Ridge (NER) (Clemens et al., 2016) (Fig. 1c). Site U1443 is located $100 \mathrm{~m}$ southeast of Ocean Drilling Program (ODP) Site

180758 and is a re-drill of this legacy site (Shipboard Scientific Party, 1989). At Site U1443, the use of Advanced Piston Coring (APC) and half-length APC drilling techniques down to $>200 \mathrm{~m}$ CSF (core depth below sea floor) in three holes allowed recovery of a compete, spliced Neogene sedimentary section spanning 0-195 m CCSF (core composite depth below sea floor). Late Miocene records cover the interval $70.06 \mathrm{~m} \mathrm{CCSF}(\mathrm{U} 1443 \mathrm{~B} 7 \mathrm{H} 5 \mathrm{~W} 75-76 \mathrm{~cm}$ ) to $122.76 \mathrm{~m} \mathrm{CCSF}$ (U1443C $15 \mathrm{H} 4 \mathrm{~W}$ 148-149 cm), following the revised shipboard splice (CCSF-D), spanning the interval $\sim 5 \mathrm{Ma}$ to 9.5 Ma based on initial bio-magneto-stratigraphy. Samples come from lithologic Units Ib and IIa, and sediments mainly consist of light grey to pale yellow nannofossil ooze with clay and foraminifers, and occasional volcanic ash (Clemens et al., 2016). To minimise aliasing due to low estimated sedimentation rates $(\sim 0.5-2 \mathrm{~cm} / \mathrm{kyr}), 1 \mathrm{~cm}$ thick half rounds $(\sim 18 \mathrm{cc})$ were sampled for micropaleontology. Cores were sampled at a depth resolution of $4 \mathrm{~cm}$ in the upper part of the study interval (70.06-114.18 $\mathrm{m}$ ) and $2 \mathrm{~cm}$ in the lower part (114.18-122.76 $\mathrm{m})$ where sedimentation rate estimates were lower. U-channels for XRF scanning were sampled from archive halves of sediment cores at Kochi Core Centre (Japan) during the post-cruise sampling party for 39 sections included in the splice between U1443C 9H 2A (69.95 m CCSF) and U1443C 13H 5A (113.58 m CCSF).

Modern oceanographic conditions over the seasonal cycle above Site U1443 were assessed using recent datasets (Figs. 1a-b, 2). Monthly data for wind (Wind Stress, Metop-A ASCAT, $0.25^{\circ}$, Global, Near Real Time, 2009-present) (Fig. 2a), MLD (1969-2010) (Keerthi et al., 2013) (Fig. 2b) and depth-integrated NPP estimated from satellite-derived surface chlorophyll concentrations (Primary Productivity, Aqua MODIS, NPP, Global, 2003-present, EXPERIMENTAL (Monthly Composite) calculated using method of Behrenfeld and Falkowski (1997); (Erd, 2020)) (Fig. 2c) were extracted for a box between $\sim 4.5-5.5^{\circ} \mathrm{N}$ latitude and $89-91^{\circ} \mathrm{E}$ longitude (depending on grid resolution) and binned by month. Scatter thus reflects a combination of spatial variability within our small box and interannual variability; monthly means over each time series are also shown. POC, 
biogenic $\mathrm{SiO}_{2}$, and $\mathrm{CaCO}_{3}$ fluxes (Fig. $2 \mathrm{~d}$, e) are from $\mathrm{SBBT}$ sediment trap samples $\left(\sim 5^{\circ} \mathrm{N}, 87^{\circ} \mathrm{E}\right.$, Fig. 1c) (Unger et al., 2003). In Fig. 2 we show data from the deep traps ( 3000 m, 21 day sampling intervals) (Rixen et al., 2019), but seasonal patterns of biogenic particle flux are very similar in the shallow ( 1000 m) SBBT traps (Unger and Jennerjahn, 2009; Vidya et al., 2013). Data points show fluxes recorded in individual years (1987-1997, plotted against mid-time for the trap deployment), with monthly averages also shown. Monthly wind and NPP data were downloaded from the ERDDAP server (https://coastwatch.pfeg.noaa.gov/erddap/index.html) and Indian Ocean MLD data (Keerthi et al., 2013) from http://www.ifremer.fr/cerweb/deboyer/mld/Surface_Mixed_Layer_Depth.php.

\subsection{Late Miocene benthic foraminiferal stable isotope data}

Bulk sediment samples were oven-dried at $50^{\circ} \mathrm{C}$, weighed, and washed over a $63 \mu \mathrm{m}$ sieve in tap water at CEREGE. The $>63 \mu \mathrm{m}$ fraction was oven-dried at $50^{\circ} \mathrm{C}$ on a filter paper and weighed to determine percentage coarse fraction. The $<63 \mu \mathrm{m}$ fraction was centrifuged and dried at $50^{\circ} \mathrm{C}$. Depth resolution for the benthic isotope record is $8 \mathrm{~cm}$ (70.06 $\mathrm{m}$ to $112.87 \mathrm{~m} \mathrm{CCSF}), 4 \mathrm{~cm}(112.86$ $\mathrm{m}$ and 114.18 $\mathrm{m} \mathrm{CCSF}$ ) or 2cm (114.18-122.76 m CCSF), except near splice tie-points where sampling included overlap between cores increasing resolution. Six to twelve specimens of the epibenthic foraminiferal species Cibicidoides wuellerstorfi were picked from the $>212 \mu \mathrm{m}$ fraction, with 6-8 well-preserved specimens selected for analysis. Tests were broken into fragments, cleaned in ethanol in an ultrasonic bath, and oven dried at $40^{\circ} \mathrm{C}$. Stable carbon and oxygen isotopes were

225 measured on a Thermo Scientific MAT 253 dual-inlet isotope ratio mass spectrometer (DI-IRMS) coupled to Kiel IV carbonate preparation device at the Leibniz Laboratory, University of Kiel. Based on long-term analysis of international and internal carbonate standards, precision $(1 \sigma)$ is better than $\pm 0.08 \%$ or for $\delta^{18} \mathrm{O}$ and $0.05 \%$ for $\delta^{13} \mathrm{C}$. Results were calibrated using the National Institute of Standard and Technology (NIST) carbonate isotope standard NBS (National Bureau of

230 Standard) 19, and are reported on the Vienna PeeDee Belemnite (VPDB) scale. C. wuellerstorfi isotope data below 112.86 m CCSF were originally published in Lübbers et al. (2019), and a lowresolution version of the long-term $\delta^{13} \mathrm{C}$ record is included in Bretschneider et al. (submitted).

\subsection{Age model}

235 Seven calcareous nannofossil bio-events dated between 5.04 Ma and 9.53 Ma were identified at high-resolution in Site U1443 splice samples (Table S1) to increase the resolution of shipboard biostratigraphy (Robinson et al., 2016). To check for orbital periodicities prior to tuning, wavelet 
analyses were performed on benthic isotope records in the depth domain and on the revised nannofossil-based age model (using a $4^{\text {th }}$ order polynomial fit, Fig. S1) in R using the biwavelet package (Gouhier et al., 2016; Grinsted et al., 2004) (Fig. S2a-d). All time-series were first interpolated to constant depth or age resolution, such that the maximum resolution present was preserved ( $2 \mathrm{~cm}$ and $2 \mathrm{kyr}$ for benthic isotope records in the depth and age domain, respectively). Records were then filtered to remove signals with periods longer than one third of the length of the dataset using the "bandpass" function in the R package Astrochron (Meyers, 2014). Wavelets indicate that obliquity-driven cycles are present throughout $(\sim 0.53 \mathrm{~m}$, Fig S2 a-b; $41 \mathrm{kyr}$ and $53 \mathrm{kyr}$, Fig. S2 c-d), confirming that the U1443 record is suitable for orbital tuning. Using revised nannofossil datums (Table S1, Fig. S1) and shipboard magnetostratigraphy (Clemens et al., 2016) as preliminary age-depth tie-points (Fig. 3), an astronomical age model was constructed by tuning our monospecific benthic $\delta^{18} \mathrm{O}$ record to an eccentricity plus tilt (ET) target curve (Laskar et al., 2004) (Fig. 4). We did not include precession in our tuning target so as not to introduce assumptions related to which hemisphere was controlling climate at our site, and because the temporal resolution of our benthic record does not permit accurate resolution of precession cycles in some intervals. We used a minimal tuning approach, tying ET maxima to benthic $\delta^{18} \mathrm{O}$ minima, with at most one tiepoint per $\sim 100 \mathrm{kyr}$ and often one every 200-300 kyr (Fig. 4, Fig. S1), so as not to artificially introduce frequency modulations (Zeeden et al., 2015).

\subsection{XRF Scanning and Calibration}

U-channels were scanned at $1 \mathrm{~cm}$ intervals at The Australian National University (ANU) on a third generation Avaatech XRF core scanner. All cores were scanned sequentially and standards measured daily were consistent across all runs. Core sections were covered with 4 micron-thick Ultralene film and measured at $10 \mathrm{kv}$ with a $500 \mu \mathrm{A}$ current and no filter, then at $30 \mathrm{kv}$ with a 200 $\mu \mathrm{A}$ current and $\mathrm{Pd}$ thin filter, and finally at $50 \mathrm{kv}$ with a $50 \mu \mathrm{A}$ current and $\mathrm{Cu}$ filter. A 30 sec count time was used for all runs. Late Miocene XRF data generated at ANU (72.75-113.56m CCSF) were spliced with data from Lübbers et al. (2019) (112.80m to 122.76m CCSF), also scanned on an

265 Avaatech XRF core scanner but with different machine settings. To splice the records, we rescaled the raw Lübbers et al. (2019) elemental count data so that absolute values and variance matched our data, based on an overlapping interval between 112.80 and $113.56 \mathrm{~m} \mathrm{CCSF}$.

Quantitative chemical compositions of a subset of discrete bulk sediment samples were determined at CEREGE after total digestion by Inductively Coupled Plasma Mass Spectrometer (ICP-MS 
Agilent 7500 ce). Twenty samples from the scanned late Miocene interval, selected to cover the range of values in the raw XRF count data for elements of interest, were analysed and concentrations of Al, K, Ca, Ti, Mn, Fe, Rb, Sr, and Ba were determined. Prior to analysis, samples were dried and homogenised in a pestle and mortar. About $30 \mathrm{mg}$ of sediment was completely dissolved by acid digestion using a 2:1 mixture of ultrapure acids (15 $\mathrm{M} \mathrm{HNO}_{3}$ and $22 \mathrm{M} \mathrm{HF}$ with $\mathrm{HClO}_{4}$ ) on a hot plate. Blank contribution was estimated to be negligible. The accuracy of measurements was evaluated using analysis of geostandards MAG-1(marine mud) and BE-N (basalt). The typical analytical uncertainty was better than 5\%. XRF-derived element counts were converted into element concentrations by direct linear calibration. This allowed us to reduce uncertainties related to the variable matrix effect and physical properties such as moisture content that typically change downcore. Additionally, we used calibrated XRF data to calculate biogenic barium concentrations and to estimate $\% \mathrm{CaCO}_{3}$ and "carbonate-free basis" (cfb) elemental concentrations, permitting evaluation of the extent to which dilution by the dominant sediment constituent (here $\mathrm{CaCO}_{3}$ ) is driving trends and variability of more minor constituents in our records.

285 To represent the relative contributions of $\mathrm{CaCO}_{3}$ versus terrigenous sediment components, we use the $\log$ count ratio of $\mathrm{Ca} /\left(\sum(\mathrm{Al}, \mathrm{K}, \mathrm{Ti}, \mathrm{Fe}, \mathrm{Rb})\right)$, termed $\log (\mathrm{Ca} / \mathrm{Terr})$.

\subsection{Ba-based export productivity proxies}

The accumulation of biogenic barium in sediments is a reliable proxy for export production in certain environments (Paytan and Griffith, 2007). Micron-sized barite $\left(\mathrm{BaSO}_{4}\right)$ crystals are the main carriers of particulate barium in the ocean, with a maximum in concentration occurring just below the euphotic zone (Bishop, 1988; Dehairs et al., 1980). Although the exact mechanisms governing the precipitation of barite in the water column are only now coming to light (Martínez-Ruiz et al., 2019), its formation is thought to be associated with decaying organic matter. Depth profiles of dissolved Ba suggest that passive adsorption of barite onto mainly biogenic particles as they sink through the water column, combined with vertical mixing of dissolved Ba from the deep ocean and riverine input, can best explain Ba's nutrient-like water column distribution (Dehairs et al., 1980; Cao et al., 2016). Goldberg and Arrhenius (1958) first hypothesised that an increase in Ba accumulation rate in sediments underlying the equatorial Pacific divergence zone was directly linked to overlying high productivity, followed by similar observations in equatorial Indian Ocean sediments (Schmitz, 1987). Subsequently, evidence for strong correlations between fluxes of Ba and organic carbon in Atlantic and Pacific sediment traps led to algorithms relating new productivity to particulate Ba flux (Dymond et al., 1992; Francois et al., 1995). A further study 
focusing on the accumulation of barite (Babarite) extracted from core-top and late Pleistocene sediments refined its use as a proxy for export productivity (Paytan et al., 1996). Although significant Ba regeneration occurs in the uppermost few millimetres of sediment (Paytan and Kastner, 1996), barite dissolution is thought to cease after burial due to supersaturation in interstitial waters (Gingele and Dahmke, 1994; Dymond et al., 1992) and barite is not subject to burial diagenesis in oxic sediments (Paytan et al., 1993). Ocean sedimentary Ba has both a biogenic $\left(\mathrm{Ba}_{\mathrm{bio}}\right)$ and a terrigenous $\left(\mathrm{Ba}_{\text {detrital }}\right)$ component, so estimates of past export productivity using barium must distinguish between these sources. This can either be done by chemical leaching of bulk sediment (assuming that all barite is Ba $a_{\text {bio }}$ ) e.g. (Paytan et al., 1996), or by determination of total barium $\left(\mathrm{Ba}_{\text {total }}\right)$ and subtraction of $\mathrm{Ba}_{\text {detrital }} \mathrm{using} \mathrm{Al}$ content and the terrigenous $\mathrm{Ba} / \mathrm{Al}$ ratio, resulting in a record of $\mathrm{Ba}_{\mathrm{xs}}\left(\mathrm{Ba}_{\text {total }}-\mathrm{Ba}_{\text {detrital }}\right)$, see equation 1 (Dymond et al., 1992).

$\left[\mathrm{Ba} \mathrm{as}_{\mathrm{ppm}}=\left[\mathrm{Ba} \mathrm{atotal}_{\mathrm{ppm}}-\left(\mathrm{Ba} / \mathrm{Al}_{\text {terrigenous }}\right) *\left[\mathrm{Al}_{\text {total }}\right]_{\mathrm{ppm}}\right.\right.$

Direct comparisons of measurements of Babarite and $\mathrm{Ba}_{\mathrm{xs}}$ suggest that non-barite phases of barium may be included in the calculation of $\mathrm{Ba}_{\mathrm{xs}}$; nevertheless $\mathrm{Ba}_{\mathrm{xs}}$ is most representative of $\mathrm{Ba}_{\text {barite }}$ and therefore export productivity in oxic carbonate-rich sediments with low terrigenous, biogenic silica, and organic carbon contents (Eagle et al., 2003; Averyt and Paytan, 2004; Gonneea and Paytan, 2006). The use of bulk $\mathrm{Ba} / \mathrm{Ti}, \mathrm{Ba} / \mathrm{Al}$, and $\mathrm{Ba} / \mathrm{Fe}$ ratios is another approach to evaluate relative changes in export productivity (i.e., normalisation to an element presumed to be predominantly of terrigenous origin), but without precisely predefining the $\mathrm{Ba} /$ terrigenous ratio that could vary over 325 time, and also removing the effect of dilution by a dominant sedimentary component such as $\mathrm{CaCO}_{3}$ (Murray et al., 2000).

Here, we reconstruct changes in export productivity at Site U1443 over the late Miocene using XRF-derived $\mathrm{Ba}$ data and compare elemental count ratios of $\log (\mathrm{Ba} / \mathrm{Fe}), \log (\mathrm{Ba} / \mathrm{Ti})$, and $\log (\mathrm{Ba} / \mathrm{Al})$, with $[\mathrm{Ba}]_{\mathrm{cfb}}$ and $[\mathrm{Ba}]_{\mathrm{xs}}$ calculated following equation (1), using a $\mathrm{Ba} / \mathrm{Al} l_{\text {terrigenous value of }}$ $0.0075 \mathrm{~g} / \mathrm{g}$ following Dymond et al. (1992). To verify consistency of trends, we also calculate $[\mathrm{Ba}]_{\mathrm{xs}}$ using [Ti] to represent $\mathrm{Ba}_{\text {detrital }}$, applying a $\mathrm{Ba} / \mathrm{Ti}_{\text {terrigenous }}$ ratio of $0.183 \mathrm{~g} / \mathrm{g}$ (Mclennan, 2001), and carbonate-free $[\mathrm{Ba}]_{\mathrm{xs}}$. 


\subsection{Mass Accumulation rates}

MARs of bulk sediment, $\mathrm{CaCO}_{3},[\mathrm{Ba}]_{\mathrm{xs}}$, and summed terrigenous elements ( $\mathrm{Al}, \mathrm{K}, \mathrm{Ti}, \mathrm{Fe}$, and $\mathrm{Rb}$ ) were calculated by multiplying concentrations by linear sedimentation rates (in $\mathrm{cm} / \mathrm{kyr}$ ) derived from our new age model and dry bulk densities (in $\mathrm{g} / \mathrm{cm}^{3}$ ). Dry bulk density values were estimated from high-resolution shipboard Gamma Ray Attenuation bulk density scanning data, and the linear relationship between all shipboard U1443 wet bulk density and dry bulk density measurements $\left(n=164, r^{2}>0.99\right)$ (Clemens et al., 2016). Units are $\mathrm{g} / \mathrm{cm}^{2} / \mathrm{kyr}$ for bulk and $\mathrm{CaCO}_{3} \mathrm{MAR}$, $\mu \mathrm{g} / \mathrm{cm}^{2} / \mathrm{kyr}$ for $[\mathrm{Ba}]_{\mathrm{xs}} \mathrm{MAR}$ and $\mathrm{mg} / \mathrm{cm}^{2} / \mathrm{kyr}$ for terrigenous MAR.

\subsection{Time series analysis}

345 Spectral analyses of benthic isotope and XRF data against tuned age were performed on filtered records with a constant time step as described in Section 2.3 ( $0.5 \mathrm{kyr}$ for XRF records and $2 \mathrm{kyr}$ for isotope records). Multi-taper method (MTM) spectral analyses using a robust red-noise model were performed using Acycle (Li et al., 2019). Blackman-Tukey cross-spectral analyses were performed in Arand to assess phase and coherence (Howell et al., 2006). Wavelet analyses were performed in $\mathrm{R}$ using the biwavelet package (Gouhier et al., 2016; Grinsted et al., 2004). To illustrate precessionband variance and amplitude modulation, certain records (with identified significant precession variance) were filtered using a Tanner-Hilbert filter centred on 43 cycles/myr with bandwidth \pm 3 (designed to include both the $\sim 24 \mathrm{kyr}$ and $\sim 22 \mathrm{kyr}$ precession periods) in Acycle (Li et al., 2019).

\section{Results}

\subsection{Age model and benthic foraminiferal isotope data}

$\mathrm{U} 1443$ benthic $\delta^{18} \mathrm{O}$ and $\delta^{13} \mathrm{C}$ data between $70.06 \mathrm{~m}$ and $122.76 \mathrm{~m} \mathrm{CCSF}$ are shown in the depth domain in Figure 3 alongside calcareous nannofossil datums (revised herein, Table S1) and magnetochron boundaries. Our tuned benthic $\delta^{18} \mathrm{O}$ and $\delta^{13} \mathrm{C}$ records, shown in Figure 4, span the interval 4.96 Ma to $8.99 \mathrm{Ma}$ and our age model shows excellent agreement with revised biostratigraphic and shipboard magnetostratigraphic datums (Fig. S1). Sedimentation rates generally vary between 1 and $1.7 \mathrm{~cm} / \mathrm{kyr}$, with a minimum of $\sim 0.5-0.7 \mathrm{~cm} / \mathrm{kyr}$ in the oldest part of the record ( 8.6 to $9 \mathrm{Ma}$ ) and a maximum of $\sim 1.9 \mathrm{~cm} / \mathrm{kyr}$ at $7.8-8 \mathrm{Ma}$ (Fig. $4 \mathrm{~d}$ ). We note that between $112.86 \mathrm{~m}$ and $121 \mathrm{~m} \mathrm{CCSF}$ (8.7-8.1 Ma), our age model differs by up to $60 \mathrm{kyr}$ from that of Lübbers et al. (2019), which is based on correlation of Site $\mathrm{U} 1443$ benthic $\delta^{18} \mathrm{O}$ and $\delta^{13} \mathrm{C}$ data to 
the orbitally tuned ODP Site $1146 \delta^{13} \mathrm{C}$ record (Holbourn et al., 2018) using a limited number of tie points (Site locations in Fig. 1c). Wavelet analyses (Fig. $4 \mathrm{f}, \mathrm{g}$ ) as well as spectral analyses (Fig. $\mathrm{S} 2 \mathrm{e}, \mathrm{f}$ ) of the tuned benthic records reveal significant orbital periodicities ( $>99 \%$ significance level) of $\sim 405 \mathrm{kyr}$ and $41 \mathrm{kyr}$ for $\delta^{18} \mathrm{O}$ and $\sim 405 \mathrm{kyr}, 125 \mathrm{kyr}, 95 \mathrm{kyr}, 53 \mathrm{kyr}$ and $41 \mathrm{kyr}$ for $\delta^{13} \mathrm{C}$, and filtered isotope records show good correspondence with filtered ET (Fig. 4h). Cross-spectral analysis between $\delta^{18} \mathrm{O}$ and $\delta^{13} \mathrm{C}$ reveals $>95 \%$ coherency in the $41 \mathrm{kyr}$ and $405 \mathrm{kyr}$ bands (Fig. $\mathrm{S} 3 \mathrm{a})$. Our age model is supported by close agreement between Site $\mathrm{U} 1443$ benthic $\delta^{18} \mathrm{O}$ and $\delta^{13} \mathrm{C}$ data and independent orbitally-tuned benthic isotope records from the South China Sea (ODP 1146) (Holbourn et al., 2018; Holbourn et al., In Press), equatorial Pacific (IODP Sites U1338 and 1337)

375 (Drury et al., 2016; Drury et al., 2018; Drury et al., 2017), and equatorial Atlantic (ODP Sites 926 and 999) (Bickert et al., 2004; Shackleton and Hall, 1997; Drury et al., 2017; Zeeden et al., 2013) (Figs S4, S5).

Mean temporal resolution of the Site U1443 benthic isotope record is $4.2 \mathrm{kyr}$. Between $9 \mathrm{Ma}$ and 7.6 Ma, mean benthic $\delta^{18} \mathrm{O}$ values vary between 2.5 and $2.8 \%$, with an overall decreasing trend culminating in minimum values averaging $\sim 2.4 \%$ between 7.6 and $7 \mathrm{Ma}$ (Fig. 4c). Between 7 and $6.5 \mathrm{Ma}$, mean $\delta^{18} \mathrm{O}$ values increase by $\sim 0.25 \%$, and between 6.5 and $5 \mathrm{Ma}$, mean values vary between 2.55 and $2.8 \%$. Between 6 and $5 \mathrm{Ma}$, a number of prominent benthic $\delta^{18} \mathrm{O}$ maxima are identified in the $\mathrm{U} 1443 \delta^{18} \mathrm{O}$ record, namely TG2, TG12, TG14, TG20 and TG22 (following nomenclature of Shackleton et al. (1995)) (Fig. 4c). Between 7.7 and 6.9 Ma, strong obliquity modulation of the U1443 $\delta^{18} \mathrm{O}$ record is seen (Fig. 4f), as also noted at Sites U1337 (Drury et al., 2017) and 1146 (Holbourn et al., 2018) (Fig. S4). Long-term trends are similar to those recorded at Pacific sites, with benthic $\delta^{18} \mathrm{O}$ values at Indian Ocean Site U1443 0.1\%o heavier than at Pacific Sites U1337/U1338 and $\sim 0.2-0.3 \%$ heavier than at South China Sea Site 1146 (Fig. 5a).

Mean benthic $\delta^{13} \mathrm{C}$ values at Site U1443 vary between 0.7 and $1.1 \%$ from 9 to $7.6 \mathrm{Ma}$, then decrease from $\sim 1$ to $-0.2 \%$ between 7.6 and $6.7 \mathrm{Ma}$, reflecting the globally recognised Late Miocene Carbon Isotope Shift (LMCIS) (Keigwin, 1979; Keigwin and Shackleton, 1980) (Fig. 4e). From 6.7 to $5 \mathrm{Ma}$, mean values vary between -0.2 and $0.4 \%$. The timing of the LMCIS at Site $395 \mathrm{U} 1443$ ( 7.6 Ma to $\sim 6.7 \mathrm{Ma}$ ) is synchronous with the event in independent orbitally-tuned highresolution records (Drury et al., 2018; Drury et al., 2017; Holbourn et al., 2018; Drury et al., 2016) (Fig. 5b, Fig. S5), and its magnitude ( $\sim 1 \%$ decrease in $\delta^{13} \mathrm{C}$ in smoothed record) is similar to that recorded in Pacific Ocean sediments from Sites U1338, U1337 and 1146. The Site U1443 $\delta^{13} \mathrm{C}$ 
record shows a consistent positive offset of 0.15-0.25 \%o relative to South China Sea Site 1146 over the 9-5 Ma interval (Fig. 5b).

\subsection{XRF data and calibration}

Scanning XRF results are shown in Figure 6. Linear calibration between element counts and concentrations in discrete samples over the late Miocene interval ( 8.15 to $5 \mathrm{Ma})$ showed significant coefficients of determination, with $\mathrm{R}^{2}$ values ranging from $0.68(\mathrm{Al})$ to $0.87(\mathrm{Fe})$ (Fig. S6), excluding Sr and Ca (see explanation below). Raw and calibrated elemental data show consistent trends and amplitude variability (Fig. 6). For Ti, Ba, Al, and Mn, the re-scaled counts/sec values in the 113.37-122.76 m CCSF interval (Lübbers et al., 2019) fell outside of our calibration range, thus data below $113.6 \mathrm{~m}(\sim 8.15 \mathrm{Ma})$ were not converted to concentrations (Fig. 6). In brief,

$410 \mathrm{Al}, \mathrm{Si}, \mathrm{Ti}, \mathrm{Fe}, \mathrm{Rb}$, and $\mathrm{K}$ show similar trends, with a long-term small increase in concentrations from 8.15 Ma to $5 \mathrm{Ma}$ and spikes (particularly pronounced in $\mathrm{Rb}$ and $\mathrm{K}$ ) corresponding in some cases to described ash layers (Clemens et al., 2016). Ca and Ba show a minor long-term decrease over the study interval, while $\mathrm{Sr}$ and $\mathrm{Mn}$ increase from $\sim 8.15 \mathrm{Ma}$ to $6 \mathrm{Ma}$, then stabilise or decrease slightly. All elements show high-frequency variability throughout. For $\mathrm{Ca}$ and $\mathrm{Sr}, \mathrm{R}^{2}$ values were

415 lower (0.39 and 0.42 respectively, Fig S6) due to the consistently high Ca and Sr contents and small variability in the selected calibration samples. To estimate percent $\mathrm{CaCO}_{3}$, we therefore used a $\mathrm{Ca} / \mathrm{Fe}$ ratio calibration rather than a direct linear calibration. We first used the linear relationship between $\mathrm{Ca} / \mathrm{Fe}$ counts and $\mathrm{Ca} / \mathrm{Fe}$ as determined by ICP-MS (Fig. S6, $\mathrm{R}^{2}=0.93$ ). Then $\% \mathrm{CaCO}_{3}$ was calculated assuming that all $\mathrm{Ca}$ was contained in $\mathrm{CaCO}_{3}-$ a reasonable assumption at Site U1443 given the relatively low clay content in lithological subunits Ib and IIa (Clemens et al., 2016). Confidence in our method is provided by very good agreement with independent $\% \mathrm{CaCO}_{3}$ estimates for the middle and early late Miocene interval of Site U1443 based on calibration of XRFderived counts of $\left(\mathrm{Ca} / \sum(\mathrm{Ca}, \mathrm{Al}, \mathrm{Si}, \mathrm{K}, \mathrm{Ti}, \mathrm{Mn}, \mathrm{Fe}, \mathrm{S})\right)$ to discrete $\mathrm{CaCO}_{3}$ measurements (Lübbers et al., 2019), including an overlapping interval based on an alternate splice from 112.8 and $113.6 \mathrm{~m}$

425 CCSF (Fig. 7b).

\section{3 $\mathrm{CaCO}_{3}$ content, sediment accumulation patterns and Ba proxies}

Late Miocene estimated \% $\mathrm{CaCO}_{3}$ varies between $\sim 60$ and $90 \%$ with a small long-term decrease over the 9-5 Ma interval (Fig. 7b). This long-term trend is also visible in the $\log (\mathrm{Ca} / \mathrm{Terr})$ record

430 (Fig. 7c), implying a small increase in the contribution of terrigenous material relative to $\mathrm{CaCO}_{3}$ in Site $\mathrm{U} 1443$ sediments over time. Three $\% \mathrm{CaCO}_{3}$ and $\log (\mathrm{Ca} / \mathrm{Terr})$ minima between 5 and $6 \mathrm{Ma}$ 
occur in identified ash layers. $\log (\mathrm{Ba} / \mathrm{Al}), \log (\mathrm{Ba} / \mathrm{Fe})$ and $\log (\mathrm{Ba} / \mathrm{Ti})$ show identical long-term and orbital-scale trends (Fig. S7), therefore we only discuss $\log (\mathrm{Ba} / \mathrm{Fe})$ in the main text. $\log (\mathrm{Ba} / \mathrm{Fe})$ shows a long-term decrease between 9 and 5.3 Ma, and a smaller increase from 5.3 to $5 \mathrm{Ma}$ (Fig. 7d). $[\mathrm{Ba}]_{\mathrm{xs}}$ shows identical variability whether calculated using Al or Ti (Fig. 7e), and generally shows similar patterns to $\log (\mathrm{Ba} / \mathrm{Fe})$ where records overlap $(8.15$ to $5 \mathrm{Ma})$. Values of $[\mathrm{Ba}]_{\mathrm{xs}}$ generally vary between 400-800 ppm, however carbonate-free $[\mathrm{Ba}]_{\mathrm{xs}}$ concentrations are typically 1000 to 4000 ppm (Fig. S7). A peak in $\log (\mathrm{Ba} / \mathrm{Fe})$ between 7.6 and $7.3 \mathrm{Ma}$ is less pronounced in the $[\mathrm{Ba}]_{\mathrm{xs}}$ record, but is prominent in the carbonate-free $[\mathrm{Ba}]_{\mathrm{xs}}$ record (Fig. S7, grey shading), suggesting that this peak is supressed in the $[\mathrm{Ba}]_{\mathrm{xs}}$ record as a result of dilution by carbonate. The trough between 7.6 and 7.9 Ma seen in $\log (\mathrm{Ba} / \mathrm{Fe}),[\mathrm{Ba}]_{\mathrm{xs}}$ and to a lesser extent in $\% \mathrm{CaCO}_{3}$, $\log (\mathrm{Ca} /$ Terr $)$, and carbonate-free $[\mathrm{Ba}]_{\mathrm{xs}}$ appears not to be an artefact of dilution.

Bulk sediment MARs vary between 0.5 and $2.1 \mathrm{~g} / \mathrm{cm}^{2} / \mathrm{kyr}$ with a step increase from $\sim 0.5$ to 1.5 $\mathrm{g} / \mathrm{cm}^{2} / \mathrm{kyr}$ occurring at $8.66 \mathrm{Ma}$ (Fig. $7 \mathrm{~g}$ ), concurrent with a major sedimentation rate increase (Fig. 4d). $\mathrm{CaCO}_{3} \mathrm{MARs}$ range from 0.4 to $2 \mathrm{~g} / \mathrm{cm}^{2} / \mathrm{kyr}$ and co-vary with bulk sediment MARs, with the increasing difference between the two records reflecting a small long-term increase in non- $\mathrm{CaCO}_{3}$ components (Fig. 7g). This small increase is reflected in terrigenous element MARs, which vary between $\sim 20-80 \mathrm{mg} / \mathrm{cm}^{2} / \mathrm{kyr}$ (excluding volcanic ash layers) (Fig. 7i). We note that absolute values of terrigenous MAR should be interpreted with caution, because this calculation does not include $\mathrm{Si}$ as this element was not quantified in discrete samples. Nevertheless, a significant correlation between $\mathrm{Al}$ and $\mathrm{Si}$ counts $\left(\mathrm{R}^{2}=0.8\right.$, Fig. 6) suggests that $\mathrm{Si}$ is primarily of terrigenous origin, therefore trends in $\log (\mathrm{Ca} /$ Terr $)$ and terrigenous MAR in Fig. 7 are likely robust despite the exclusion of Si. From 8.3-5 Ma, [Ba $]_{x s}$ MAR shows similar patterns to $\mathrm{CaCO}_{3} \mathrm{MAR}$, with no clear long-term trend and maximum values driven by higher sedimentation rates in the intervals 5-5.2 Ma, 6.1-6.3 Ma, 7.5-7.7 Ma, and 7.8-8 Ma (Fig. 7f).

Spectral analyses reveal significant orbital periods in all late Miocene XRF records (Fig. 8). The $\sim 405 \mathrm{kyr}$ period is $>99 \%$ significant in [Al], $[\mathrm{Ba}],[\mathrm{Ba}]_{\mathrm{cfb}},[\mathrm{Ba}]_{\mathrm{xs}}$, and $\log (\mathrm{Ba} / \mathrm{Fe})$, whereas the $\sim 125$ kyr period is significant $(>95 \%$ or $>99 \%)$ in $[\mathrm{Ba}],[\mathrm{Ba}]_{\mathrm{cfb}},[\mathrm{Ba}]_{\mathrm{xs}}, \log (\mathrm{Ba} / \mathrm{Fe})$, and $\% \mathrm{CaCO}_{3}$ records. At higher frequencies, the spectral signatures of [Fe], [Al], [Ti], [Ba], are dominated by significant peaks at $24 \mathrm{kyr}(>99 \%)$ and $41 \mathrm{kyr}(>90 \%)$, with [Ba] additionally showing peaks at $22.5 \mathrm{kyr}$ $(>99 \%)$ and at 26 and $30 \mathrm{kyr}(>95 \%) . \log (\mathrm{Ba} / \mathrm{Fe}),[\mathrm{Ba}]_{\mathrm{cfb}}$, and $[\mathrm{Ba}]_{\mathrm{xs}}$ show dominant $(>99 \%$ significant) $22.5 \mathrm{kyr}$ variability, with additional $>95 \%$ significant peaks at $24 \mathrm{kyr}$ and $30 \mathrm{kyr}$ (for $[\mathrm{Ba}]_{\mathrm{xs}}$ only). $\log (\mathrm{Ca} /$ Terr) shows significant peaks at 24 and $22.5 \mathrm{kyr}$ (both $>99 \%$ ), and also at 68 
kyr (>95\%). Percent $\mathrm{CaCO}_{3}$ contains significant (>95\%) variability at $22.5 \mathrm{kyr}$, with additional peaks at $68 \mathrm{kyr}$ and $37 \mathrm{kyr}$. In summary, all records show highly significant variability in the precession band (22-24 kyr), with variability at the $22.5 \mathrm{kyr}$ period and the $\sim 125 \mathrm{kyr}$ period most strongly associated with the biogenic component of $\mathrm{Ba}$ and with $\mathrm{CaCO}_{3}$. Wavelet analyses of $\log (\mathrm{Ba} / \mathrm{Fe})$ and $[\mathrm{Ba}]_{\mathrm{xs}}$ confirm significant precession-scale variability in these records throughout the 9-5 Ma interval (Fig. 9).

\section{Discussion}

\subsection{Late Miocene sedimentation patterns in the southern Bay of Bengal}

475 We first examine the drivers of changes in sediment MAR identified in our record, and their possible link to regional and global productivity trends. The three-fold increase in $\mathrm{CaCO}_{3} \mathrm{MAR}$ at 8.66 Ma at Site U1443, originally described in Lübbers et al. (2019), could result from improved preservation and/or increased carbonate export by pelagic calcifiers (coccolithophores and/or foraminifera). Based on $\mathrm{CaCO}_{3}$ percentages, MARs, and benthic to planktic foraminiferal ratios, Lübbers et al. (2019) identified the mid to late Miocene "carbonate crash" in Site U1443 sediments between $\sim 12.2 \mathrm{Ma}$ and $10 \mathrm{Ma}$, with a slow recovery from $\sim 10$ to $8.7 \mathrm{Ma}$, favouring an interpretation that the increase in $\mathrm{CaCO}_{3} \mathrm{MAR}$ at $8.66 \mathrm{Ma}$ reflects improved preservation. A record of planktic foraminiferal fragmentation between 9 and 8 Ma generated in the present study, interpreted to reflect a decrease in carbonate dissolution (Le and Shackleton, 1992), supports this interpretation (Fig. 7h). We see no change in $\log (\mathrm{Ba} / \mathrm{Fe})$ concurrent with the $\mathrm{CaCO}_{3} \mathrm{MAR}_{\text {increase }}$ at $8.66 \mathrm{Ma}$, which suggests that total export productivity at Site U1443 remained stable over this transition. However, our data suggest that an increase in coccolithophore production may have occurred. The contribution of foraminifera to total $\mathrm{CaCO}_{3}$ over our study interval is low (see $>63$ $\mu \mathrm{m}$ MAR in Fig. 7g), leading us to infer that higher $\mathrm{CaCO}_{3} \mathrm{MARs}$ between 8.66 and $5 \mathrm{Ma}$ are primarily driven by coccoliths. A 3-fold increase in sediment accumulation rate (SAR) at $\sim 8.6 \mathrm{Ma}$ with no change in $\mathrm{CaCO}_{3}$ content (\%), implying a large increase in $\mathrm{CaCO}_{3} \mathrm{MARs}$, is also seen at shallower (2247 m) Deep Sea Drilling Project (DSDP) Site 216 on the NER near the equator (Fig. 1c) (Bukry, 1974; Mcneill et al., 2017; Pimm, 1974). This suggests that production played a role in driving regional carbonate MAR increases as well as improved preservation at deeper sites. A recent study decoupling coccolith and foraminiferal MARs in relatively shallow, globallydistributed sites (minimally affected by dissolution) records a late Miocene pulse in coccolith MARs beginning at 8-9 Ma and persisting until 3-4 Ma, interpreted to reflect high 
coccolithophore productivity and calcification driven by weathering alkalinity inputs and regional nutrient changes (Si and Rosenthal, 2019).

500

Interestingly, the increase in bulk MARs at $8.66 \mathrm{Ma}$ is driven by both $\mathrm{CaCO}_{3}$ and to a lesser extent non- $\mathrm{CaCO}_{3}$ components (clays), implicating another mechanism as well as improved carbonate preservation and increased coccolith export productivity affecting sedimentation at Site U1443. We suggest that an increase in coccolith $\mathrm{CaCO}_{3}$ flux to the seafloor could have led to increased

505 scavenging by sinking biogenic aggregates of fine clays. Fine clays are present in the southern BOB water column as a direct result of riverine flux (Rixen et al., 2019; Ramaswamy, 1993), and in nepheloid layers above the NER where high clay concentrations occur due to proximity to the sedimentary fan systems to the east (Nicobar Fan) and west (Bengal Fan) (Stow et al., 1990). Recent studies of sedimentation patterns on the Bengal and Nicobar Fans, separated by the NER,

510 interpret a large increase in SAR both on the NER and the Nicobar Fan at $\sim 10-8$ Ma to reflect increased lithogenic sediment flux to the eastern Indian Ocean (Mcneill et al., 2017; Pickering et al., 2020 b). Our data from the NER show that $>75 \%$ of the 3 -fold increase in SAR at $8.66 \mathrm{Ma}$ is driven by biogenic $\mathrm{CaCO}_{3}$, thus we caution against using SAR at Site U1443/758 as representative of changes in sediment flux to the Bengal-Nicobar Fan system. Data from Site U1443, as well as from

515 nearby DSDP Site 216 (Bukry, 1974; Mcneill et al., 2017; Pimm, 1974) (Fig. 1c), suggest that increases in biogenic carbonate accumulation on the NER are decoupled, both temporally and mechanistically, from the increase in sediment delivery to the Nicobar Fan system. The gradual increase in terrigenous element and non- $\mathrm{CaCO}_{3} \mathrm{MARs}$ over the 9-5 Ma interval seen at Site U1443 (Fig. $7 \mathrm{~g}, \mathrm{i}$ ) is part of a longer-term trend of increasing mineral flux in this region of the NER from

520 the Miocene to the Pleistocene, beginning at $\sim 12 \mathrm{Ma}$ at ODP Site 758, that is thought to reflect increased Himalayan erosion (Ali et al., 2021; Hovan and Rea, 1992).

Increases in the MAR of biogenic components $\left(\mathrm{CaCO}_{3}\right.$, opal, organic carbon, phosphorus) between $\sim 9$ and 4 Ma have been measured in sediments from the Pacific, Indian and Atlantic Oceans (Farrell et al., 1995; Lyle and Baldauf, 2015; Van Andel et al., 1975; Grant and Dickens, 2002; Delaney and Filippelli, 1994; Hermoyian and Owen, 2001; Dickens and Owen, 1999; Drury et al., 2020). This period of increased biogenic sedimentation, supported by independent paleoproductivity proxies (e.g., Diester Haass et al., 2005), is thought to reflect higher biological productivity and was dubbed the "biogenic bloom" by Farrell et al. (1995). A low-resolution $\mathrm{CaCO}_{3}$ MAR record from Site 758

530 shows higher values between 8 and $4 \mathrm{Ma}$, which in the absence of evidence for an increase in carbonate dissolution at $4 \mathrm{Ma}$, could suggest an end to the biogenic bloom at this site in the early 
Pliocene (Dickens and Owen, 1999; Pierce et al., 1989; Si and Rosenthal, 2019), although improved age control for the Pliocene interval as well as independent paleoproductivity reconstructions are needed to verify this. Hypotheses to explain the biogenic bloom invoke a change in global nutrient cycling; i.e., a global increase in nutrient input, and/or redistribution of nutrients between basins (Grant and Dickens, 2002), although the asynchronous timing of the biogenic bloom between regions, its variable expression, and its differentiation from the carbonate crash recovery complicate its interpretation. Diester Haass et al. (2006) hypothesised that changes in reconstructed productivity were correlated to the LMCIS at four Indo-Pacific sites, and tentatively proposed a link to a strengthened wind regime at this time. At Site U1443, we find no clear link between export productivity or carbonate sedimentation and the LMCIS (Fig. 7). In the northern Indian Ocean, the influence of possible concurrent changes in monsoon strength on paleoproductivity and biogenic MARs must also be considered, and these are discussed in Section 4.3.

\subsection{Orbital forcing of late Miocene South Asian summer monsoon winds}

On orbital timescales, time series analyses reveal dominant precession-band (22-24 kyr) variance in late Miocene export productivity records (Fig. 8, 9). Spectral analyses of individual calibrated timeseries of [Ba], [Al], [Fe], [Ti], [Ba $]_{\mathrm{cfb}}$ and $\% \mathrm{CaCO}_{3}$ allow us to tease apart the effects of sediment dilution and the competing influence of $\mathrm{Ba}_{\text {terr }}$ and $\mathrm{Ba}_{\mathrm{bio}}$ on our $\mathrm{Ba}$ proxies, $[\mathrm{Ba}]_{\mathrm{xs}}$ and $\log (\mathrm{Ba} / \mathrm{Fe})$. The $41 \mathrm{kyr}$ obliquity period is most significant $(>90 \%)$ in the terrigenous element records $(\mathrm{Al}, \mathrm{Fe}, \mathrm{Ti}, \mathrm{Ba})$, and absent or less significant in $[\mathrm{Ba}]_{\mathrm{xs}}, \log (\mathrm{Ba} / \mathrm{Fe}), \log (\mathrm{Ca} / \mathrm{Terr})$, and $\% \mathrm{CaCO}_{3}$ (Fig 8). The $24 \mathrm{kyr}$ period stands out as highly significant in all records $(>99 \%$, except for $\% \mathrm{CaCO}_{3}$ and $[\mathrm{Ba}]_{\mathrm{cfb}}$ where $>95 \%$ ). In contrast, the $125-\mathrm{kyr}$ and $22.5 \mathrm{kyr}$ peaks that dominates the $[\mathrm{Ba}]_{\mathrm{xs}}$ and $\log (\mathrm{Ba} / \mathrm{Fe})$ spectra $(>99 \%$ significant $)$, are also highly significant only in the $[\mathrm{Ba}]$,

$555[\mathrm{Ba}]_{\mathrm{cfb}}, \% \mathrm{CaCO}_{3}$, and $\log (\mathrm{Ca} / \mathrm{Terr})$ records. This suggests that strong variability at the $125-\mathrm{kyr}$ (eccentricity) and $22.5 \mathrm{kyr}$ (precession) periods is related to biological productivity (i.e. Babio and not $\mathrm{Ba}_{\text {detrital}}$, as well as biogenic $\mathrm{CaCO}_{3}$ ). The 30-kyr peak in $[\mathrm{Ba}]_{\mathrm{xs}}$ is also seen in [Ba] but not in [Fe], [Al], or [Ti], so we similarly interpret this period as being related to biological productivity. The 23.6-kyr and 22.3-kyr periods (highlighted together in Fig. 8 as one grey band spanning 22-24

$560 \mathrm{kyr}$ ) are primary periods of Earth's precession, whereas the 53-kyr and 41-kyr periods are related to Earth's obliquity (Laskar et al., 2004).

Significant variability at obliquity and precession periods has been identified in high-resolution late Miocene-early Pliocene records of precipitation/runoff based on planktic foraminiferal $\delta^{18} \mathrm{O}$ and 

a distinct switch to obliquity-driven variability around $5.55 \mathrm{Ma}$, their records reflect strong precessional (insolation) control on South Asian monsoon rainfall from 6.2-5.55 Ma, with significant phase lags between proxies and precession. Wavelet analyses of $\log (\mathrm{Ba} / \mathrm{Fe})$ and $[\mathrm{Ba}]_{\mathrm{xs}}$ show that precession-band (22-24 kyr) variability dominated throughout our 9-5 Ma study interval at Site U1443 (Fig. 9). Although phase relationships with insolation should be interpreted with caution because of errors inherent to our late Miocene age model, export productivity appears to be coherent and in phase (within error) with the summer inter-tropical insolation gradient (SITIG, the insolation gradient between $23^{\circ} \mathrm{N}$ and $23^{\circ} \mathrm{S}$ on June $21^{\text {st }}$ ) (Fig. S3d). The SITIG has been proposed as a primary control on the strength of SASM winds, because a stronger SITIG increases the

575 pressure gradient between the two limbs of the winter hemisphere Hadley cell, which drives monsoon winds into the summer hemisphere (Bosmans et al., 2015). Our new Ba-based export productivity records corroborate the hypothesis that insolation played a dominant role in driving late Miocene South Asian summer monsoon wind variability in the equatorial sector of the SAM region, as predicted by general circulation models (Bosmans et al., 2018), with internal climate processes such as ice volume playing a more minor role than in the Late Pleistocene when large glacial-interglacial cycles and related feedbacks drove variability in the Asian monsoon on 100-kyr timescales (Clemens et al., 2018; Clemens et al., 2021) and SASM wind proxies from the Arabian Sea and southern BOB record up to $\sim 9$ kyr phase lags relative to precession (Bolton et al., 2013; Caley et al., 2011; Clemens and Prell, 2003; Clemens et al., 1991).

In addition to the periods discussed above, a number of non-primary orbital periods termed heterodynes, which result from non-linear interactions between variables operating at Earth's primary orbital periods (Rial and Anaclerio, 2000; Thomas et al., 2016; Clemens et al., 2010), stand out in our late Miocene records (24, 26, 30, 37, 49, and 68 kyr periods; Fig. 8). For example, the

$5901 / 24$ kyr heterodyne, prominent in all our records, could result from the interference of eccentricity with precession, and the 1/30 kyr heterodyne seen in Ba records from an interaction between obliquity and precession. Several of these heterodynes have been previously identified in spectra of seawater $\delta^{18} \mathrm{O}$ that reflect Asian monsoon precipitation and runoff, both in the Andaman Sea (30 and 130 kyr during the Pleistocene, 27 and 30 kyr in the latest Miocene) (Gebregiorgis et al., 2018; 595 Jöhnck et al., 2020) and in the East China Sea (29 and 69 kyr during the Pleistocene) (Clemens et al., 2018), interpreted to suggest a strongly non-linear response of the monsoon to orbital forcing. We favour the interpretation that the strong 24-kyr variability in our records reflects a primary period of precession, because precession filters of $[\mathrm{Ba}]_{\mathrm{xs}}$ and $\log (\mathrm{Ba} / \mathrm{Fe})$ spanning 22-25 kyr show 
strong amplitude modulation of the precession signal at a period of $\sim 405 \mathrm{kyr}$, which results from the interaction of the 23.6-kyr and 22.3-kyr periods $(1 /[(1 / 22.3)-(1 / 23.6)]=404.8 \mathrm{kyr})($ Fig. 10). Amplitude modulation of precession-scale variability in our productivity records broadly follows that of the SITIG (Fig. 10), suggesting a direct response of SASM winds to cross-equatorial insolation gradients during the late Miocene.

605 Cross-spectral analysis of our $[\mathrm{Ba}]_{\mathrm{xs}}$ productivity record with the Site $\mathrm{U} 1448$ seawater $\delta^{18} \mathrm{O}$ record over the interval 4.95-6.19 Ma (where records overlap) shows $>80 \%$ coherency and an in-phase relationship at the 30-kyr period, suggesting that during this time monsoon winds and precipitation/runoff in the BOB were to some degree coupled on orbital timescales (Fig. S3c), as is the case in the late Pleistocene (Clemens et al., 2021). Nevertheless, our [Ba $]_{\mathrm{xs}}$ record over this time

610 window contains stronger primary precession (22-24 kyr) and obliquity (41 kyr) signals than the Site $\mathrm{U} 1448$ seawater $\delta^{18} \mathrm{O}$ record that cannot be explained by differences in resolution, highlighting that different climatic processes and feedbacks operating on orbital timescales must contribute to the two records (interpreted to reflect runoff/precipitation and wind, respectively) to different extents. In the late Pleistocene, strong obliquity-band and precession-band variance is found in

615 Andaman Sea records of monsoon precipitation/runoff (Gebregiorgis et al., 2018), whereas records of upper ocean stratification controlled by South Asian monsoon wind mixing at Site 758 ( 100 m from Site U1443) show only precession-band variance (Bolton et al., 2013). The significant 41-kyr variability seen in late Miocene terrigenous elements at Site U1443 (Fig. 8a-c) could also suggest obliquity control on monsoon runoff into the BOB at this time, inferring a partial decoupling

620 between monsoon winds (controlling open-ocean productivity) and runoff (controlling terrigenous sedimentation and salinity/seawater $\delta^{18} \mathrm{O}$ ) on orbital timescales, although additional records from regions closer to river sediment and freshwater sources are needed to corroborate this idea. It is important to note that whilst SAM expression above Site U1443 in the southern BOB is dominated by summer monsoon winds driving surface ocean currents and deeper mixing, oceanographic conditions in the northern and eastern BOB (e.g., Sites U1447 and U1448) are instead primarily controlled by summer monsoon freshwater inputs (Jöhnck et al., 2020; Kuhnt et al., 2020). Runoff and direct precipitation during the SASM lead to strong salinity stratification in the northern parts of the BOB in the late summer and autumn that prevents upper ocean mixing (e.g., Sengupta et al., 2016). These regional differences in the manifestation of the monsoon must be considered when interpreting records from the heterogeneous $\mathrm{BOB}$, and records from multiple locations and proxies are needed to achieve a representative picture of the SAM subsystem. 
The 405 kyr eccentricity modulation of precession-scale export productivity variability broadly coincides with 405-kyr cycles in benthic $\delta^{13} \mathrm{C}$ at Site U1443, with higher export productivity occurring during benthic $\delta^{13} \mathrm{C}$ minima and eccentricity maxima on these timescales (Fig. 10). Cross-spectral analysis indicates that $\log (\mathrm{Ba} / \mathrm{Fe})$ and benthic $\delta^{13} \mathrm{C}$ are $>95 \%$ coherent at the $\sim 405$ kyr and 22-24 kyr periods, with an in-phase relationship in the precession band $\left(-13^{\circ} \pm 25\right)$ and a near antiphase relationship on $405-\mathrm{kyr}$ timescales $\left(151^{\circ} \pm 27\right)$ (Fig. S3b). 405-kyr modulation of the ocean carbon cycle, primarily recorded in carbonate content and benthic $\delta^{13} \mathrm{C}$ records (Herbert, 1997; Drury et al., 2020; De Vleeschouwer et al., 2020; Westerhold et al., 2020; Pälike et al., 2012; Paillard, 2017; Holbourn et al., 2007) but also in productivity and monsoon-related dust records (Rickaby et al., 2007; Wang et al., 2010), has been observed throughout the Cenozoic and Mesozoic sedimentary record. In middle Miocene records, poor carbonate preservation noted during eccentricity maxima is interpreted as indicating transient shoaling of the carbonate compensation depth (Holbourn et al., 2007; Flower and Kennett, 1994). Here, we see a broad positive correlation between $\log (\mathrm{Ba} / \mathrm{Fe})$ and $\log (\mathrm{Ca} /$ Terr) records on $405-\mathrm{kyr}$ timescales (Figs. 9a,b), suggesting that carbonate content fluctuations at Site U1443 in the late Miocene were more strongly related to biogenic production than to dissolution on long eccentricity timescales. The coincidence of late Miocene eccentricity maxima with productivity maxima and benthic $\delta^{13} \mathrm{C}$ minima at Site U1443 is compatible with the hypothesis that during eccentricity maxima, a strengthened monsoon induced 405-kyr cycles in the marine carbon cycle via increased weathering and nutrient inputs, leading to enhanced marine biological productivity and deep-ocean organic carbon burial (Ma et al., 2011).

\subsection{Late Miocene monsoon evolution}

On long timescales, our Site U1443 biogenic Ba records show relatively stable (9 to $6.5 \mathrm{Ma}$ ) or slightly decreasing (6.5-5.3 Ma) export productivity between 9 and 5 Ma (Fig. 7d-f, Fig. S7). Based on sediment colour properties and XRF-derived $\mathrm{Ba} / \mathrm{Ti}$ ratios in the preceding interval $(\sim 13.5-8.3$ Ma), Lübbers et al. (2019) suggested that a shift towards a higher productivity regime at Site U1443 occurred at 11.2 Ma, significantly earlier than the onset of the biogenic bloom at other sites and 2.5 Ma before the rise in $\mathrm{CaCO}_{3} \mathrm{MAR}$, and that this shift was potentially linked to an intensification of the South Asian monsoon. An increase in export productivity at $\sim 11 \mathrm{Ma}$ is coherent with longterm changes in benthic foraminiferal assemblages at Site 758 (Gupta et al., 2004; Nomura, 1995) and at sites in the western tropical Indian Ocean (Smart et al., 2007). Reconstructions of Arabian Sea upwelling, export productivity, and deoxygenation (Bialik et al., 2020; Gupta et al., 2015; 
Maldives Archipelago at 13 Ma (Betzler et al., 2016), point towards an intensification of seasonally-reversing South Asian monsoon winds between 13-11 Ma, consistent with Site U1443 export productivity records. Our new data suggest that similar levels of export productivity to those seen from 11.2 Ma to 9 Ma persisted until at least 5 Ma at Site U1443.

Compiled Asian monsoon proxy records spanning the 9 to $5 \mathrm{Ma}$ interval show relatively stable long-term SASM strength (Fig. 11, see Fig. 1c for site map). In line with records from the Maldives and Arabian Sea (Tripathi et al., 2017; Huang et al., 2007; Betzler et al., 2016; Zhuang et al., 2017), Site U1443 records do not corroborate the hypothesis that SASM winds intensified at $\sim 7-8$ Ma as suggested by some studies (Kroon et al., 1991; Singh and Gupta, 2014; Gupta et al., 2015; An et al., 2001). A recent modelling study suggests that the emergence of the Arabian Peninsula played a key role in the establishment of modern Somali Jet structure above the western Indian Ocean, initiating strong upwelling along the Oman margin during the Miocene (Sarr et al., in review). This provides a potential explanation for the temporal decoupling between western Arabian Sea records and

680 SASM records from other regions, and suggests that Arabian Sea upwelling records should not be interpreted as exclusive recorders of SASM strength on geological timescales. The long-term trend in our record shows broad agreement with a low-resolution clay mineralogy record from Site U1447 in the Andaman Sea showing gradual long-term decrease in smectite/(illite and chlorite) over the late Miocene (Fig. 11g), indicating strengthened physical weathering and/or weakened chemical weathering, attributed to the South Asian winter and summer monsoons respectively (Lee et al., 2020). Also at Site U1447, records of potassium content (\%K, Fig. 11x) are interpreted to show a shift in sediment provenance and/or an increase in physical weathering and erosion in the sediment source region between $\sim 7$ and $\sim 6 \mathrm{Ma}$ (Fig. 11h), potentially linked to an increase in monsoon rainfall intensity and global cooling (Kuhnt et al., 2020). Between 6.2 and 5 Ma, our equatorial Indian Ocean wind records show good long-term agreement with a seawater $\delta^{18} \mathrm{O}$ record from the Andaman Sea (Jöhnck et al., 2020), with a minimum in export productivity at $~ 5.3 \mathrm{Ma}$ at Site $U 1443$ coinciding with a maximum in seawater $\delta^{18} \mathrm{O}$ at Site U1448 (Fig. 11i, j). One interpretation of this could be a coupled reduction in both SASM wind intensity and runoff/precipitation over this interval, although Jöhnck et al. (2020) invoke an increase in local evaporation and/or a change in precipitation source to explain the decreasing seawater $\delta^{18} \mathrm{O}$ values between 5.6 and 5.2 Ma. High-resolution records of precipitation and runoff from the SASM region further back in time are needed to verify to what extent monsoon winds and precipitation/runoff are coupled on long timescales. 
In contrast to the relatively stable South Asian monsoon between 9 and $5 \mathrm{Ma}$, evidence for a step strengthening of the East Asian winter monsoon during the late Miocene ( $\sim 7 \mathrm{Ma})$ comes from the South China Sea (Holbourn et al., 2018) (Fig. 11a), whereas records from a site on the Chinese Loess Plateau suggest a more gradual intensification of the East Asian summer monsoon from 8.2 to 2.6 Ma (Fig. 11b). The step change in South China Sea surface water geochemistry is interpreted to reflect drying and cooling of the Asian interior and a related southward shift of the ITCZ leading to an intensified dry winter monsoon over southeast Asia (Holbourn et al., 2018). The long-term increase in East Asian summer monsoon strength inferred from magnetic records in Chinese loess sequences is attributed to progressive Antarctic glaciation that drives an increased pressure gradient between the Australian High and Asian Low pressure cells, a mechanism supported by numerical

710 simulations (Ao et al., 2016). However, we note that these single site records may not be representative of the East Asian monsoon subsystem as a whole. Conversely, the apparent insensitivity of equatorial SASM wind intensity to global late Miocene sea surface cooling, which began at 7.5 Ma and culminated in an SST minimum at 6 to $5.5 \mathrm{Ma}$ (Fig. 11k) (Herbert et al., 2016), is consistent with climate modelling studies that show limited impact of different $p \mathrm{CO}_{2}$ scenarios on SASM wind patterns and strength (Kitoh et al., 1997; Sarr et al., in review). The South Asian monsoon is widely considered to be a thermally direct circulation, driven by the thermodynamic contrast between the Indian subcontinent and the equatorial Indian Ocean that develops in summer, with changes in this gradient impacting the strength of onshore SASM monsoon flow (Lutsko et al., 2019; Acosta and Huber, 2020). The lack of a long-term trend in wind and surface circulation proxies over the 9 to $5 \mathrm{Ma}$ interval (Fig. 11) suggests a relatively constant land-sea temperature gradient despite global cooling. Thus, our data add to the body of evidence suggesting decoupling between the East Asian and South Asian monsoons on long timescales.

\section{Summary \& Conclusions}

725 We present new equatorial Indian Ocean benthic $\delta^{13} \mathrm{C}$ and $\delta^{18} \mathrm{O}$ records and an age model spanning the interval between 9 and $5 \mathrm{Ma}$ (late Miocene-earliest Pliocene), and analyse sedimentation and productivity trends and cyclicity using XRF-derived records and MARs. Biogenic sediment MARs reveal a modest imprint of the late Miocene biogenic bloom at Site U1443 lasting until at least 5 Ma, primarily driven by fine-fraction (coccolith) $\mathrm{CaCO}_{3}$ accumulation, as noted at other sites ( $\mathrm{Si}$ and Rosenthal, 2019). Nevertheless, the carbonate MAR record of Site U1443 is clearly influenced by carbonate preservation as well as production over the late Miocene, so independent productivity proxies must be considered when defining the duration of the biogenic bloom. Our results indicate 
that step increases in SAR recorded on the Ninetyeast Ridge at $\sim 8-9$ Ma primarily reflect an increase in $\mathrm{CaCO}_{3}$ accumulation, and that this is likely independent from the increase in lithogenic sediment flux recorded in nearby Nicobar Fan sites, itself related to sediment re-routing within the Nicobar-Bengal Fan system around the same time (Mcneill et al., 2017; Pickering et al., 2020a).

Our data show no long-term increase in export productivity between 9 and $5 \mathrm{Ma}$ (and by inference no intensification of SASM winds), therefore these data support existing evidence for an early late Miocene ( 13-10 Ma) establishment of strong seasonally reversing South Asian monsoon winds and Arabian Sea upwelling, with relatively stable or slightly weakening SASM winds over the remainder of the late Miocene and earliest Pliocene between 9 and $5 \mathrm{Ma}$. Spectral and crossspectral analyses of XRF-based biogenic barium records reveal that export productivity in waters overlying Site U1443 was consistently paced by precession, with amplitude modulation of the precession signal on $\sim 405 \mathrm{kyr}$ timescales and no significant variability at glacial-interglacial (obliquity) timescales. Coeval late Miocene productivity maxima and benthic $\delta^{13} \mathrm{C}$ minima during eccentricity maxima at Site U1443 provides support for the hypothesis that the monsoon may have paced changes in the carbon cycle on 405 kyr timescales (Ma et al., 2011). Significant coherence and an in-phase relationship at the precession band between biogenic barium and the SITIG suggests direct forcing of South Asian monsoon winds by insolation gradients over the late

750 Miocene, relatively unaffected by glacial boundary conditions and long-term global cooling trends (Herbert et al., 2016). In contrast, East Asian summer and winter monsoons appear to have intensified during the late Miocene in response to global cooling and Antarctic ice sheet growth and related feedbacks (Ao et al., 2016; Holbourn et al., 2018), although more continuous records over the late Miocene are needed to understand regional trends due to the heterogeneous nature of Asian monsoon expression.

\section{Data Availability}

All data will be available on the www.pangaea.de database (submitted 18.06.2021, awaiting validation)

\section{Supplement Link}

\section{Author contributions}

C.T.B. designed the study. Sample processing and picking of benthic foraminifera was carried out by E.G and C.T.B. Picked foraminifera samples were verified and cleaned by A.H., W.K., and J.L., 
and stable isotopes measurements were performed by N.A., A.H., W.K., and J.L. XRF scanning was carried out by C.T.B. in collaboration with K.G., G.M., and E.J.R. XRF calibration was carried out by E.G. and K.T. The manuscript was written by C.T.B with feedback from all authors.

\section{Competing Interests}

The authors declare that they have no conflict of interest.

\section{Acknowledgements}

This research used samples and data provided by the International Ocean Discovery Program (IODP). We thank the science party, technical staff and crew of IODP Expedition 353. Funding for

775 this research was provided by French ANR project iMonsoon ANR-16-CE01-0004-01 (CTB), IODP France (CTB), and Deutsche Forschungsgemeinschaft grant Ku649/36-1(WK). KMG is supported by Australian Research Council grant DE190100042. CTB thanks Anna Joy Drury and Tim Herbert for age model feedback, and Luc Beaufort, Baptiste Suchéras-Marx, and Ian Bailey for discussions that helped improve the manuscript. Marta Garcia Molina, Jean-Charles Mazur, and Christine Pailles are thanked for technical laboratory support at CEREGE.

\section{References}

Acosta, R. and Huber, M.: Competing topographic mechanisms for the summer Indo-Asian monsoon, Geophysical Research Letters, 47, e2019GL085112, 2020.

Ali, S., Hathorne, E., and Frank, M.: Persistent provenance of South Asian Monsoon induced silicate weathering over the past 27 million years, Paleoceanography and Paleoclimatology, accepted, 2021.

An, Z., Kutzbach, J. E., Prell, W. L., and Porter, S. C.: Evolution of Asian monsoons and phased uplift of the Himalaya-Tibetan plateau since Late Miocene times, nature, 411, 62-66, 2001.

An, Z., Clemens, S. C., Shen, J., Qiang, X., Jin, Z., Sun, Y., Prell, W. L., Luo, J., Wang, S., and Xu, H.: Glacial-interglacial Indian summer monsoon dynamics, science, 333, 719-723, 2011.

Ao, H., Roberts, A. P., Dekkers, M. J., Liu, X., Rohling, E. J., Shi, Z., An, Z., and Zhao, X.: Late Miocene-Pliocene Asian monsoon intensification linked to Antarctic ice-sheet growth, Earth and Planetary Science Letters, 444, 75-87, 2016.

Averyt, K. B. and Paytan, A.: A comparison of multiple proxies for export production in the equatorial Pacific, Paleoceanography, 19, 2004.

Behrenfeld, M. J. and Falkowski, P. G.: Photosynthetic rates derived from satellite-based chlorophyll concentration, Limnology and oceanography, 42, 1-20, 1997.

800 Behrenfeld, M. J., Boss, E., Siegel, D. A., and Shea, D. M.: Carbon-based ocean productivity and phytoplankton physiology from space, Global biogeochemical cycles, 19, 2005.

Betzler, C., Eberli, G., Lüdmann, T., Reolid, J., Kroon, D., Reijmer, J., Swart, P., Wright, J., Young, J., and Alvarez-Zarikian, C.: Refinement of Miocene sea level and monsoon events 

Science, 5, 1-18, 2018.

Betzler, C., Eberli, G. P., Kroon, D., Wright, J. D., Swart, P. K., Nath, B. N., Alvarez-Zarikian, C. A., Alonso-García, M., Bialik, O. M., and Blättler, C. L.: The abrupt onset of the modern South Asian Monsoon winds, Scientific reports, 6, 29838, 2016.

Bialik, O. M., Auer, G., Ogawa, N. O., Kroon, D., Waldmann, N. D., and Ohkouchi, N.: Monsoons, upwelling, and the deoxygenation of the northwestern Indian Ocean in response to middle to late Miocene global climatic shifts, Paleoceanography and Paleoclimatology, 35, 2020.

Bickert, T., Haug, G., and Tiedemann, R.: Late Neogene benthic stable isotope record of ODP Site 999: Implications for Caribbean paleoceanography, organic carbon burial and the Messinian Salinity Crisis, Paleoceanography, 19, PA1023, 2004.

Bishop, J. K.: The barite-opal-organic carbon association in oceanic particulate matter, Nature, 332, 341-343, 1988.

Bolton, C. T., Chang, L., Clemens, S. C., Kodama, K., Ikehara, M., Medina-Elizalde, M., Paterson, G. A., Roberts, A. P., Rohling, E. J., and Yamamoto, Y.: A 500,000 year record of Indian summer monsoon dynamics recorded by eastern equatorial Indian Ocean upper watercolumn structure, Quaternary Science Reviews, 77, 167-180, 10.1016/j.quascirev.2013.07.031, 2013.

Boos, W. R. and Kuang, Z.: Dominant control of the South Asian monsoon by orographic insulation versus plateau heating, Nature, 463, 218-222, 2010.

825 Bosmans, J., Hilgen, F., Tuenter, E., and Lourens, L.: Obliquity forcing of low-latitude climate, Climate of the Past, 11, 1335-1346, 2015.

Bosmans, J., Erb, M., Dolan, A., Drijfhout, S., Tuenter, E., Hilgen, F., Edge, D., Pope, J. O., and Lourens, L.: Response of the Asian summer monsoons to idealized precession and obliquity forcing in a set of GCMs, Quaternary Science Reviews, 188, 121-135, 2018.

830 Bukry, D.: Coccolith and silicoflagellate stratigraphy, eastern Indian Ocean, Deep Sea Drilling Project Leg 22 in: Initial Reports of the Deep Sea Drilling Project, edited by: von der Borch, C. C., Sclater, J. G., and al., e., Washington, 10.2973/dsdp.proc.22.127.1974, 1974.

Caley, T., Malaizé, B., Zaragosi, S., Rossignol, L., Bourget, J., Eynaud, F., Martinez, P., Giraudeau, J., Charlier, K., and Ellouz-Zimmermann, N.: New Arabian Sea records help 835 decipher orbital timing of Indo-Asian monsoon, Earth and Planetary Science Letters, 308, 433-444, 10.1016/j.eps1.2011.06.019, 2011.

Cao, Z., Siebert, C., Hathorne, E. C., Dai, M., and Frank, M.: Constraining the oceanic barium cycle with stable barium isotopes, Earth and Planetary Science Letters, 434, 1-9, 2016.

Clemens, S. C. and Prell, W. L.: Late Pleistocene variability of Arabian Sea summer monsoon winds and continental aridity: Eolian records from the lithogenic component of deep-sea sediments, Paleoceanography, 5, 109-145, 1990.

Clemens, S. C. and Prell, W. L.: A 350,000 year summer-monsoon multi-proxy stack from the Owen Ridge, Northern Arabian Sea, Marine Geology, 201, 35-51, 10.1016/S00253227(03)00207-X, 2003.

845 Clemens, S. C., Prell, W. L., and Sun, Y.: Orbital-scale timing and mechanisms driving Late Pleistocene Indo-Asian summer monsoons: Reinterpreting cave speleothem $\delta 18 \mathrm{O}$, Paleoceanography, 25, 2010.

Clemens, S. C., Prell, W., Murray, D., Shimmield, G., and Weedon, G.: Forcing mechanisms of the Indian Ocean monsoon, Nature, 353, 720-725, DOI 10.1038/353720a0, 1991.

850 Clemens, S. C., Holbourn, A., Kubota, Y., Lee, K., Liu, Z., Chen, G., Nelson, A., and FoxKemper, B.: Precession-band variance missing from East Asian monsoon runoff, Nature communications, 9, 1-12, 2018. 
Clemens, S. C., Yamamoto, M., Thirumalai, K., Giosan, L., Richey, J. N., Nilsson-Kerr, K., Rosenthal, Y., Anand, P., and McGrath, S. M.: Remote and local drivers of Pleistocene South Asian summer monsoon precipitation: A test for future predictions, Science Advances, 7 , eabg3848, 2021.

Clemens, S. C., Kuhnt, W., LeVay, L. J., Anand, P., Ando, T., Bartol, M., Bolton, C. T., Ding, X., Gariboldi, K., Giosan, L., Hathorne, E., Huang, Y., Jaiswal, P., Kim, S., Kirkpatrick, J. B., Littler, K., Marino, G., Martinez, P., Naik, D., Peketi, A., Phillips, S. C., Robinson, M. M., Romero, O. E., Sagar, N., Taladay, K., Taylor, S. N., Thirumalai, K., Uramoto, G., Y. Usui, Wang, J., Yamamoto, M., and Zhou, L.: Site U1443, in: Indian Monsoon Rainfall.

Proceedings of the International Ocean Discovery Program, edited by: Clemens, S. C., Kuhnt, W., LeVay, L.J., and the Expedition 353 Scientists, College Station, TX (International Ocean Discovery Program), http://dx.doi.org/10.14379/iodp.proc.353.103.2016, 2016.

Clift, P. D. and Webb, A. A. G.: A history of the Asian monsoon and its interactions with solid Earth tectonics in Cenozoic South Asia, Geological Society, London, Special Publications, 483, 631-652, 2019.

Clift, P. D., Hodges, K. V., Heslop, D., Hannigan, R., Van Long, H., and Calves, G.: Correlation of Himalayan exhumation rates and Asian monsoon intensity, Nature Geoscience, 1, 875-880, 2008.

De Vleeschouwer, D., Drury, A. J., Vahlenkamp, M., Rochholz, F., Liebrand, D., and Pälike, H.: High-latitude biomes and rock weathering mediate climate-carbon cycle feedbacks on eccentricity timescales, Nature communications, 11, 1-10, 2020.

Dehairs, F., Chesselet, R., and Jedwab, J.: Discrete suspended particles of barite and the barium cycle in the open ocean, Earth and Planetary Science Letters, 49, 528-550, 1980.

Delaney, M. L. and Filippelli, G. M.: An apparent contradiction in the role of phosphorus in Cenozoic chemical mass balances for the world ocean, Paleoceanography, 9, 513-527, 1994.

Dickens, G. R. and Owen, R. M.: The latest Miocene-early Pliocene biogenic bloom: a revised Indian Ocean perspective, Marine Geology, 161, 75-91, 1999.

880 Diester Haass, L., Billups, K., and Emeis, K. C.: In search of the late Miocene-early Pliocene "biogenic bloom" in the Atlantic Ocean (Ocean Drilling Program Sites 982, 925, and 1088), Paleoceanography, 20, 2005.

Diester Haass, L., Billups, K., and Emeis, K. C.: Late Miocene carbon isotope records and marine biological productivity: Was there a (dusty) link?, Paleoceanography, 21, 2006.

Drury, A. J., John, C. M., and Shevenell, A. E.: Evaluating climatic response to external radiative forcing during the late Miocene to early Pliocene: New perspectives from eastern equatorial Pacific (IODP U1338) and North Atlantic (ODP 982) locations, Paleoceanography, 31, 167-184, 2016.

Drury, A. J., Lee, G., Gray, W., Lyle, M., Westerhold, T., Shevenell, A. E., and John, C.: Deciphering the state of the late Miocene to early Pliocene equatorial Pacific, Paleoceanography and Paleoclimatology, 33, 246-263, 2018.

Drury, A. J., Liebrand, D., Westerhold, T., Beddow, H. M., Hodell, D. A., Rohlfs, N., Wilkens, R. H., Lyle, M., Bell, D. B., and Kroon, D.: Climate, cryosphere and carbon cycle controls on Southeast Atlantic orbital-scale carbonate deposition since the Oligocene (30-0 Ma), Climate of the Past Discussions, 1-35, 2020.

Drury, A. J., Westerhold, T., Frederichs, T., Tian, J., Wilkens, R., Channell, J. E., Evans, H., John, C. M., Lyle, M., and Röhl, U.: Late Miocene climate and time scale reconciliation: Accurate orbital calibration from a deep-sea perspective, Earth and Planetary Science Letters, 475, 254-266, 2017.

900 Dymond, J., Suess, E., and Lyle, M.: Barium in deep-sea sediment: A geochemical proxy for paleoproductivity, Paleoceanography, 7, 163-181, 1992. 
Eagle, M., Paytan, A., Arrigo, K. R., van Dijken, G., and Murray, R. W.: A comparison between excess barium and barite as indicators of carbon export, Paleoceanography, 18, 2003.

ERD, N. N. S.: Primary Productivity, Aqua MODIS, NPP, Global, 2003-present, EXPERIMENTAL (Monthly Composite), erdMH1ppmday, 2020.

Farnsworth, A., Lunt, D. J., Robinson, S. A., Valdes, P. J., Roberts, W. H., Clift, P. D., Markwick, P., Su, T., Wrobel, N., and Bragg, F.: Past East Asian monsoon evolution controlled by paleogeography, not CO2, Science advances, 5, eaax1697, 2019.

Farrell, J. W., Raffi, I., Janecek, T. R., Murray, D. W., Levitan, M., Dadey, K. A., Emeis, K.-C., 910 Lyle, M., Flores, J.-A., and Hovan, S.: Late Neogene sedimentation patterns in the eastern equatorial Pacific Ocean, in: Proceedings of the Ocean Drilling Program Scientific Results, edited by: Pisias, N. G., Mayer, L. A., Janecek, T. R., Palmer-Julson, A., and van Andel, T. H., 1995.

Flower, B. P. and Kennett, J. P.: The middle Miocene climatic transition: East Antarctic ice sheet development, deep ocean circulation and global carbon cycling, Palaeogeography, palaeoclimatology, palaeoecology, 108, 537-555, 1994.

Francois, R., Honjo, S., Manganini, S. J., and Ravizza, G. E.: Biogenic barium fluxes to the deep sea: Implications for paleoproductivity reconstruction, Global Biogeochemical Cycles, 9, 289303, 1995 .

920 Gadgil, S.: The Indian monsoon and its variability, Annual Review of Earth and Planetary Sciences, 31, 429-467, 2003.

Gebregiorgis, D., Hathorne, E. C., Giosan, L., Clemens, S., Nürnberg, D., and Frank, M.: Southern Hemisphere forcing of South Asian monsoon precipitation over the past $\sim 1$ million years, Nature Communications, 9, 4702, 10.1038/s41467-018-07076-2, 2018.

925 Gingele, F. and Dahmke, A.: Discrete barite particles and barium as tracers of paleoproductivity in South Atlantic sediments, Paleoceanography, 9, 151-168, 1994.

Goldberg, E. D. and Arrhenius, G.: Chemistry of Pacific pelagic sediments, Geochimica et cosmochimica acta, 13, 153-212, 1958.

Gonneea, M. E. and Paytan, A.: Phase associations of barium in marine sediments, Marine Chemistry, 100, 124-135, 2006.

Goswami, B., Krishnamurthy, V., and Annmalai, H.: A broad-scale circulation index for the interannual variability of the Indian summer monsoon, Quarterly Journal of the Royal Meteorological Society, 125, 611-633, 1999.

Gouhier, T. C., Grinsted, A., and Simko, V.: Package 'biwavelet' [code], 2016.

935 Gradstein, F. M., Ogg, J. G., Schmitz, M. B., and Ogg, G. M.: The geologic time scale 2012, elsevier2012.

Grant, K. M. and Dickens, G. R.: Coupled productivity and carbon isotope records in the southwest Pacific Ocean during the late Miocene-early Pliocene biogenic bloom, Palaeogeography, Palaeoclimatology, Palaeoecology, 187, 61-82, 2002.

940 Grinsted, A., Moore, J. C., and Jevrejeva, S.: Application of the cross wavelet transform and wavelet coherence to geophysical time series, 2004.

Guo, Z., Ruddiman, W. F., Hao, Q., Wu, H., Qiao, Y., Zhu, R. X., Peng, S., Wei, J., Yuan, B., and Liu, T.: Onset of Asian desertification by $22 \mathrm{Myr}$ ago inferred from loess deposits in China, Nature, 416, 159-163, 2002.

945 Gupta, A. K., Singh, R. K., Joseph, S., and Thomas, E.: Indian Ocean high-productivity event (10-8 Ma): Linked to global cooling or to the initiation of the Indian monsoons?, Geology, 32, 753-756, 2004.

Gupta, A. K., Yuvaraja, A., Prakasam, M., Clemens, S. C., and Velu, A.: Evolution of the South Asian monsoon wind system since the late Middle Miocene, Palaeogeography,

$950 \quad$ Palaeoclimatology, Palaeoecology, 438, 160-167, 2015. 
Herbert, T. D.: A long marine history of carbon cycle modulation by orbital-climatic changes, Proceedings of the National Academy of Sciences, 94, 8362-8369, 1997.

Herbert, T. D., Lawrence, K. T., Tzanova, A., Peterson, L. C., Caballero-Gill, R., and Kelly, C. S.: Late Miocene global cooling and the rise of modern ecosystems, Nature Geoscience, 9, 843, 10.1038/Ngeo2813, 2016.

Hermoyian, C. S. and Owen, R. M.: Late Miocene-early Pliocene biogenic bloom: Evidence from low-productivity regions of the Indian and Atlantic Oceans, Paleoceanography, 16, 95$100,2001$.

Holbourn, A., Kuhnt, W., Clemens, S. C., and Heslop, D.: A 12 Myr record of East Asian Monsoon variability from the South China Sea, Paleoceanography and Paleoclimatology, In Press.

Holbourn, A., Kuhnt, W., Schulz, M., Flores, J.-A., and Andersen, N.: Orbitally-paced climate evolution during the middle Miocene "Monterey" carbon-isotope excursion, Earth and Planetary Science Letters, 261, 534-550, 2007.

965 Holbourn, A., Kuhnt, W., Clemens, S. C., Kochhann, K. G., Jöhnck, J., Lübbers, J., and Andersen, N.: Late Miocene climate cooling and intensification of southeast Asian winter monsoon, Nature communications, 9, 1584, 2018.

Hovan, S. A. and Rea, D. K.: The Cenozoic record of continental mineral deposition on Broken and Ninetyeast Ridges, Indian Ocean: southern African aridity and sediment delivery from the Himalayas, Paleoceanography, 7, 833-860, 1992.

Howell, P., Pisias, N., J.Ballance, Baughman, J., and Ochs, L.: ARAND Time-Series Analysis Software [code], 2006.

Huang, Y., Clemens, S. C., Liu, W., Wang, Y., and Prell, W. L.: Large-scale hydrological change drove the late Miocene $\mathrm{C}_{4}$ plant expansion in the Himalayan foreland and Arabian

975 Peninsula, Geology, 35, 531-534, doi: 10.1130/G23666A, 2007. precipitation to Earth's precession: the role of energy fluxes and vertical stability, 2019.

Jensen, T. G.: Cross-equatorial pathways of salt and tracers from the northern Indian Ocean: Modelling results, Deep Sea Research Part II: Topical Studies in Oceanography, 50, 21112127, 2003.

Jia, G., Peng, P. a., Zhao, Q., and Jian, Z.: Changes in terrestrial ecosystem since 30 Ma in East Asia: Stable isotope evidence from black carbon in the South China Sea, Geology, 31, 1093 1096, 2003.

Jöhnch, J., Holbourn, A. E., Kuhnt, W., and Andersen, N.: Oxygen isotope offsets in deep-water

985 benthic foraminifera, Journal of Faoraminiferal Research, accepted manuscript, 2021. Andaman Sea across the Miocene-Pliocene transition, Paleoceanography and Paleoclimatology, e2020PA003923, 2020.

Jyothibabu, R., Vinayachandran, P., Madhu, N., Robin, R., Karnan, C., Jagadeesan, L., and Anjusha, A.: Phytoplankton size structure in the southern Bay of Bengal modified by the Summer Monsoon Current and associated eddies: Implications on the vertical biogenic flux, Journal of Marine Systems, 143, 98-119, 2015.

Kathayat, G., Cheng, H., Sinha, A., Spötl, C., Edwards, R. L., Zhang, H., Li, X., Yi, L., Ning, Y., and Cai, Y.: Indian monsoon variability on millennial-orbital timescales, Scientific reports, 6, 24374, 2016.

Keerthi, M., Lengaigne, M., Vialard, J., de Boyer Montégut, C., and Muraleedharan, P.: Interannual variability of the Tropical Indian Ocean mixed layer depth, Climate dynamics, 40, 743-759, 2013. 
Keigwin, L.: Late Cenozoic stable isotope stratigraphy and paleoceanography of DSDP sites from the east equatorial and central North Pacific Ocean, Earth and Planetary Science Letters, 45, 361-382, 1979.

Keigwin, L. and Shackleton, N.: Uppermost Miocene carbon isotope stratigraphy of a piston core in the equatorial Pacific, Nature, 284, 613-614, 1980.

Kitoh, A., Yukimoto, S., Noda, A., and Motoi, T.: Simulated changes in the Asian summer monsoon at times of increased atmospheric CO2, Journal of the Meteorological Society of Japan. Ser. II, 75, 1019-1031, 1997.

Koné, V., Aumont, O., Lévy, M., and Resplandy, L.: Physical and biogeochemical controls of the phytoplankton seasonal cycle in the Indian Ocean: A modeling study, Indian Ocean Biogeochemical Processes and Ecological Variability, 185, 350, 2009.

1010 Kroon, D., Steens, T., and Troelstra, S. R.: 13. ONSET OF MONSOONAL RELATED UPWELLING IN THE WESTERN ARABIAN SEA AS REVEALED BY PLANKTONIC FORAMINIFERS1, Proceedings of the ocean drilling program, scientific results,

Kuhnt, W., Holbourn, A. E., Jöhnck, J., and Lübbers, J.: Miocene to Pleistocene Palaeoceanography of the Andaman Region: Evolution of the Indian Monsoon on a WarmerThan-Present Earth, in: The Andaman Islands and Adjoining Offshore: Geology, Tectonics and Palaeoclimate, Springer, 261-288, 2020.

Kutzbach, J. E.: Monsoon climate of the early Holocene: climate experiment with the earth's orbital parameters for 9000 years ago, Science, 214, 59-61, 1981.

Laskar, J., Robutel, P., Joutel, F., Gastineau, M., Correia, A. C. M., and Levrard, B.: A long-term numerical solution for the insolation quantities of the Earth, Astronomy \& Astrophysics, 428, 261-285, 2004.

Le, J. and Shackleton, N. J.: Carbonate dissolution fluctuations in the western equatorial Pacific during the late Quaternary, Paleoceanography, 7, 21-42, 1992.

Lee, J., Kim, S., Lee, J. I., Cho, H. G., Phillips, S. C., and Khim, B.-K.: Monsoon-influenced variation of clay mineral compositions and detrital $\mathrm{Nd}-\mathrm{Sr}$ isotopes in the western Andaman Sea (IODP Site U1447) since the late Miocene, Palaeogeography, Palaeoclimatology, Palaeoecology, 538, 109339, 2020.

Lévy, M., Shankar, D., André, J. M., Shenoi, S., Durand, F., and de Boyer Montégut, C.: Basinwide seasonal evolution of the Indian Ocean's phytoplankton blooms, Journal of Geophysical Research: Oceans, 112, 2007.

Li, M., Hinnov, L., and Kump, L.: Acycle: Time-series analysis software for paleoclimate research and education, Computers \& Geosciences, 127, 12-22, 10.1016/j.cageo.2019.02.011, 2019.

Licht, A., Van Cappelle, M., Abels, H., Ladant, J.-B., Trabucho-Alexandre, J., France-Lanord, C., Donnadieu, Y., Vandenberghe, J., Rigaudier, T., and Lécuyer, C.: Asian monsoons in a late Eocene greenhouse world, Nature, 513, 501-506, 2014.

Longhurst, A.: Seasonal cycles of pelagic production and consumption, Progress in oceanography, 36, 77-167, 1995.

Lübbers, J., Kuhnt, W., Holbourn, A. E., Bolton, C. T., Gray, E., Usui, Y., Kochhann, K. G., Beil, S., and Andersen, N.: The middle to late Miocene "Carbonate Crash" in the equatorial Indian Ocean, Paleoceanography and Paleoclimatology, 34, 813-832, 2019.

Lutsko, N. J., Marshall, J., and Green, B.: Modulation of monsoon circulations by crossequatorial ocean heat transport, Journal of Climate, 32, 3471-3485, 2019.

Lyle, M. and Baldauf, J.: Biogenic sediment regimes in the Neogene equatorial Pacific, IODP Palaeoecology, 433, 106-128, 2015. 
Ma, W., Tian, J., Li, Q., and Wang, P.: Simulation of long eccentricity (400-kyr) cycle in ocean carbon reservoir during Miocene Climate Optimum: Weathering and nutrient response to orbital change, Geophysical Research Letters, 38, 2011.

Martínez-Ruiz, F., Paytan, A., Gonzalez-Muñoz, M., Jroundi, F., Abad, M. d. M., Lam, P. J., Bishop, J., Horner, T., Morton, P. L., and Kastner, M.: Barite formation in the ocean: Origin of amorphous and crystalline precipitates, Chemical Geology, 511, 441-451, 2019.

McCreary, J., Murtugudde, R., Vialard, J., Vinayachandran, P., Wiggert, J. D., Hood, R. R., Shankar, D., and Shetye, S.: Biophysical processes in the Indian Ocean, Indian Ocean biogeochemical processes and ecological variability, 185, 9-32, 2009.

McLennan, S. M.: Relationships between the trace element composition of sedimentary rocks and upper continental crust, Geochemistry, Geophysics, Geosystems, 2, 2001.

McNeill, L. C., Dugan, B., Backman, J., Pickering, K. T., Pouderoux, H. F., Henstock, T. J., Petronotis, K. E., Carter, A., Chemale Jr, F., and Milliken, K. L.: Understanding Himalayan erosion and the significance of the Nicobar Fan, Earth and Planetary Science Letters, 475, 134-142, 2017.

Meyers, S. R.: Astrochron: An R Package for Astrochronology [code], 2014.

Molnar, P., Boos, W. R., and Battisti, D. S.: Orographic controls on climate and paleoclimate of Asia: thermal and mechanical roles for the Tibetan Plateau, Annual Review of Earth and

$1065 \quad$ Planetary Sciences, 38, 2010.

Müller, D. W., Hodell, D. A., and Ciesielski, P. F.: 25. Late Miocene to earliest Pliocene (9.8-4.5 Ma) paleoceanography of the subantarctic southeast atlantic: stable isotopic, sedimentologic, and microfossil evidence, in: Proceedings of the Ocean Drilling Program, Scientific Results, edited by: Ciesielski, P. F., Kristoffersen, Y., and al., e., 1991.

1070 Murray, R., Knowlton, C., Leinen, M., Mix, A. C., and Polsky, C.: Export production and carbonate dissolution in the central equatorial Pacific Ocean over the past 1 Myr, Paleoceanography, 15, 570-592, 2000.

Nigrini, C.: Composition and biostratigraphy of radiolarian assemblages from an area of upwelling (northwestern Arabian Sea, Leg 117), in: Proceedings of the Ocean Drilling

1075 Program, Scientific Results, edited by: Prell, W., Niitsuma, N., and al, e., 89-126, 1991.

Nomura, R.: Paleogene to Neogene deep-sea paleoceanography in the eastern Indian Ocean: benthic foraminifera from ODP Sites 747, 757 and 758, Micropaleontology, 251-290, 1995.

Paillard, D.: The Plio-Pleistocene climatic evolution as a consequence of orbital forcing on the carbon cycle, Climate of the Past, 13, 1259-1267, 2017.

1080 Pälike, H., Lyle, M. W., Nishi, H., Raffi, I., Ridgwell, A., Gamage, K., Klaus, A., Acton, G., Anderson, L., and Backman, J.: A Cenozoic record of the equatorial Pacific carbonate compensation depth, Nature, 488, 609-614, 2012.

Paytan, A. and Griffith, E. M.: Marine barite: Recorder of variations in ocean export productivity, Deep Sea Research Part II: Topical Studies in Oceanography, 54, 687-705, 2007.

Paytan, A. and Kastner, M.: Benthic Ba fluxes in the central Equatorial Pacific, implications for the oceanic Ba cycle, Earth and Planetary Science Letters, 142, 439-450, 1996.

Paytan, A., Kastner, M., and Chavez, F.: Glacial to interglacial fluctuations in productivity in the equatorial Pacific as indicated by marine barite, Science, 274, 1355-1357, 1996.

1090 Paytan, A., Kastner, M., Martin, E., Macdougall, J., and Herbert, T.: Marine barite as a monitor of seawater strontium isotope composition, Nature, 366, 445-449, 1993.

Pickering, K. T., Carter, A., Andò, S., Garzanti, E., Limonta, M., Vezzoli, G., and Milliken, K. L.: Deciphering relationships between the Nicobar and Bengal submarine fans, Indian Ocean, Earth and Planetary Science Letters, 544, 116329, 2020a.

1095 Pickering, K. T., Pouderoux, H., McNeill, L. C., Backman, J., Chemale, F., Kutterolf, S., Milliken, K. L., Mukoyoshi, H., Henstock, T. J., and Stevens, D. E.: Sedimentology, 
stratigraphy and architecture of the Nicobar Fan (Bengal-Nicobar Fan System), Indian Ocean: Results from International Ocean Discovery Program Expedition 362, Sedimentology, 67 , 2248-2281, 2020b.

Pierce, J., Weissel, J., and al., e.: Proceedings of the Ocean Drilling Program, Initial Reports 121, 1000 pp. pp. 1989.

Pimm, A.: Sedimentology and history of the northeastern Indian Ocean from late Cretaceous to Recent, in: Initial Reports of the Deep Sea Drilling Project, edited by: von der Borch, C. C., Sclater, J. G., and al., e., U.S. Gov. Print. Office, Washington, 717-803, $1105 \quad$ 10.2973/dsdp.proc.22.139.1974, 1974.

Prasanna Kumar, S., Muraleedharan, P., Prasad, T., Gauns, M., Ramaiah, N., De Souza, S., Sardesai, S., and Madhupratap, M.: Why is the Bay of Bengal less productive during summer monsoon compared to the Arabian Sea?, Geophysical Research Letters, 29, 88-81-88-84, 2002.

1110 Prell, W. L. and Kutzbach, J. E.: Monsoon variability over the past 150,000 years, Journal of Geophysical Research: Atmospheres, 92, 8411-8425, 1987.

Prell, W. L. and Kutzbach, J. E.: Sensitivity of the Indian monsoon to forcing parameters and implications for its evolution, Nature, 360, 17, 1992. 97, 1993.

Rial, J. A. and Anaclerio, C.: Understanding nonlinear responses of the climate system to orbital forcing, Quaternary Science Reviews, 19, 1709-1722, 2000.

Rickaby, R., Bard, E., Sonzogni, C., Rostek, F., Beaufort, L., Barker, S., Rees, G., and Schrag, D.: Coccolith chemistry reveals secular variations in the global ocean carbon cycle?, Earth 1120 and Planetary Science Letters, 253, 83-95, 2007.

Rixen, T., Gaye, B., Emeis, K.-C., and Ramaswamy, V.: The ballast effect of lithogenic matter and its influences on the carbon fluxes in the Indian Ocean, Biogeosciences, 16, 485-503, 2019.

1125 Scientists, E.: Biostratigraphic Summary, in: Proceedings of the International Ocean Discovery Program, 2016.

Rogalla, U. and Andruleit, H.: Precessional forcing of coccolithophore assemblages in the northern Arabian Sea: Implications for monsoonal dynamics during the last 200,000 years, Marine Geology, 217, 31-48, 2005.

1130 Rostek, F., Bard, E., Beaufort, L., Sonzogni, C., and Ganssen, G.: Sea surface temperature and productivity records for the past $240 \mathrm{kyr}$ in the Arabian Sea, Deep Sea Research Part II: Topical Studies in Oceanography, 44, 1461-1480, 1997.

Sarr, A.-C., Donnadieu, Y., Bolton, C. T., Ladant, J.-B., Licht, A., Fluteau, F., Laugié, M., Tardif, D., and Dupont-Nivet, G.: Reconciling South Asian Monsoon Rainfall and Wind

Histories, Nature Geoscience, in review.
Schmitz, B.: Barium, equatorial high productivity, and the northward wandering of the Indian continent, Paleoceanography, 2, 63-77, 1987.

Schott, F. A. and McCreary Jr, J. P.: The monsoon circulation of the Indian Ocean, Progress in Oceanography, 51, 1-123, 2001.

1140 Schott, F. A., Xie, S. P., and McCreary Jr, J. P.: Indian Ocean circulation and climate variability, Reviews of Geophysics, 47, 2009.

Sengupta, D., Bharath Raj, G., Ravichandran, M., Sree Lekha, J., and Papa, F.: Near-surface salinity and stratification in the north Bay of Bengal from moored observations, Geophysical Research Letters, 43, 4448-4456, 2016. 
1145 Shackleton, N. J. and Hall, M. A.: The Late Miocene stable isotope record, Site 926, in: Proc. ODP Sci. Res. 154, edited by: Shackleton, N. J., Curry, W. B., Richter, C., and Bralower, T. J., 367-373, 1997.

Shackleton, N. J., Hall, M., and Pate, D.: 15. Pliocene stable isotope stratigraphy of Site 846, Proc. Ocean Drill. Program Sci. Results, 337-355,

1150 Shimmield, G. B. and Mowbray, S. R.: The inorganic geochemical record of the northwest Arabian Sea: a history of productivity variation over the last 400 ky from sites 722 and 724, 1991.

Shipboard Scientific Party: Site 758, in: Proceedings of the ODP Initial Reports 121, edited by: J. Peirce, J. W., et al., ODP: College Station, TX, 359-453, 1989.

$1155 \mathrm{Si}, \mathrm{W}$. and Rosenthal, Y.: Reduced continental weathering and marine calcification linked to late Neogene decline in atmospheric CO 2, Nature Geoscience, 12, 833-838, 2019.

Singh, A. D., Jung, S. J., Darling, K., Ganeshram, R., Ivanochko, T., and Kroon, D.: Productivity collapses in the Arabian Sea during glacial cold phases, Paleoceanography, 26, 2011.

Singh, R. K. and Gupta, A.: Miocene history of Indian monsoon: A review of marine records, Indian Miocene: A Geodynamic and chronologic framework for palaeobiota, sedimentary environments and palaeoclimates (Ed: Tiwari RP) Special Publication of the Palaeontological Society of India, 5, 101-109, 2014.

Smart, C. W., Thomas, E., and Ramsay, A. T.: Middle-late Miocene benthic foraminifera in a western equatorial Indian Ocean depth transect: paleoceanographic implications,

1165 Palaeogeography, Palaeoclimatology, Palaeoecology, 247, 402-420, 2007.

Spicer, R., Yang, J., Herman, A., Kodrul, T., Aleksandrova, G., Maslova, N., Spicer, T., Ding, L., Xu, Q., and Shukla, A.: Paleogene monsoons across India and South China: Drivers of biotic change, Gondwana Research, 49, 350-363, 2017.

Steinthorsdottir, M., Coxall, H., de Boer, A., Huber, M., Barbolini, N., Bradshaw, C., Burls, N., Feakins, S., Gasson, E., and Henderiks, J.: The Miocene: the Future of the Past, Paleoceanography and Paleoclimatology, e2020PA004037, 2020.

Stow, D. A., Amano, K., Batson, B., Brass, G. W., Corrigan, J., Raman, C., Tiercelin, J.-J., Townsend, M., Wijayananda, N., and Cochran, J.: Sediment facies and processes on the distal Bengal Fan, Leg 116, in: Proceedings of the Ocean Drilling Project, Scientific Results, Leg

1175 116, edited by: Cochran, J. R., Stow, D. A. V., and al., e., 377-396, 1990.
Sun, X. and Wang, P.: How old is the Asian monsoon system?-Palaeobotanical records from China, Palaeogeography, Palaeoclimatology, Palaeoecology, 222, 181-222, 2005.

Tabor, C. R., Otto-Bliesner, B. L., Brady, E. C., Nusbaumer, J., Zhu, J., Erb, M. P., Wong, T. E., Liu, Z., and Noone, D.: Interpreting precession-driven $\delta 180$ variability in the South Asian 1180 monsoon region, Journal of Geophysical Research: Atmospheres, 123, 5927-5946, 2018.

Tauxe, L. and Feakins, S.: A re-assessment of the chronostratigraphy of late Miocene C3-C4 transitions, Paleoceanography and Paleoclimatology, e2020PA003857, 2020.

Thomas, E. K., Clemens, S. C., Sun, Y., Prell, W. L., Huang, Y., Gao, L., Loomis, S., Chen, G., and Liu, Z.: Heterodynes dominate precipitation isotopes in the East Asian monsoon region,

1185 reflecting interaction of multiple climate factors, Earth and Planetary Science Letters, 455, 196-206, 2016.

Tripathi, S., Tiwari, M., Lee, J., Khim, B.-K., Expedition, I., Pandey, D. K., Clift, P. D., Kulhanek, D. K., Andò, S., and Bendle, J. A.: First evidence of denitrification vis-à-vis monsoon in the Arabian Sea since Late Miocene, Scientific reports, 7, 43056, 2017.

1190 Unger, D. and Jennerjahn, T.: Impact of regional Indian Ocean characteristics on the biogeochemical variability of settling particles, GMS, 185, 257-280, 2009.

Unger, D., Ittekkot, V., Schäfer, P., Tiemann, J., and Reschke, S.: Seasonality and interannual variability of particle fluxes to the deep Bay of Bengal: influence of riverine input and 
oceanographic processes, Deep Sea Research Part II: Topical Studies in Oceanography, 50, 897-923, 2003.

Van Andel, T. H., Heath, G. R., and T.C. Moore, J.: Cenozoic History and Paleoceanography of the Central Equatorial Pacific Ocean: A Regional Synthesis of Deep Sea Drilling Project Data, in: The Geological Society of America, https://doi.org/10.1130/MEM143-p1, 1975.

Vidya, P., Prasanna Kumar, S., Gauns, M., Verenkar, A., Unger, D., and Ramaswamy, V.: Influence of physical and biological processes on the seasonal cycle of biogenic flux in the equatorial Indian Ocean, Biogeosciences Discussions, 10, 2889-2936, 2013.

Vinayachandran, P., Chauhan, P., Mohan, M., and Nayak, S.: Biological response of the sea around Sri Lanka to summer monsoon, Geophysical Research Letters, 31, 2004.

Wang, P., Tian, J., and Lourens, L. J.: Obscuring of long eccentricity cyclicity in Pleistocene oceanic carbon isotope records, Earth and Planetary Science Letters, 290, 319-330, 10.1016/j.eps1.2009.12.028, 2010.

Wang, P., Clemens, S., Beaufort, L., Braconnot, P., Ganssen, G., Jian, Z., Kershaw, P., and Sarnthein, M.: Evolution and variability of the Asian monsoon system: state of the art and outstanding issues, Quaternary Science Reviews, 24, 595-629, 2005.

1210 Webber, B. G., Matthews, A. J., Vinayachandran, P., Neema, C., Sanchez-Franks, A., Vijith, V., Amol, P., and Baranowski, D. B.: The dynamics of the Southwest Monsoon current in 2016 from high-resolution in situ observations and models, Journal of Physical Oceanography, 48, 2259-2282, 2018.

Webster, P. J.: The elementary monsoon, 1987a.

1215 Webster, P. J.: The variable and interactive monsoon, Monsoons. Wiley, New York, 269, $1987 \mathrm{~b}$.

Webster, P. J. and Yang, S.: Monsoon and ENSO: Selectively interactive systems, Quarterly Journal of the Royal Meteorological Society, 118, 877-926, 1992.

Westerhold, T., Marwan, N., Drury, A. J., Liebrand, D., Agnini, C., Anagnostou, E., Barnet, J. S., Bohaty, S. M., De Vleeschouwer, D., and Florindo, F.: An astronomically dated record of Earth's climate and its predictability over the last 66 million years, Science, 369, 1383-1387, 2020.

Zeeden, C., Meyers, S. R., Lourens, L. J., and Hilgen, F. J.: Testing astronomically tuned age models, Paleoceanography, 30, 369-383, 2015.

Zeeden, C., Hilgen, F., Westerhold, T., Lourens, L., Röhl, U., and Bickert, T.: Revised Miocene splice, astronomical tuning and calcareous plankton biochronology of ODP Site 926 between 5 and 14.4 Ma, Palaeogeography, Palaeoclimatology, Palaeoecology, 369, 430-451, 2013.

Zhisheng, A., Clemens, S. C., Shen, J., Qiang, X., Jin, Z., Sun, Y., Prell, W. L., Luo, J., Wang, $\mathrm{S}$., and $\mathrm{Xu}, \mathrm{H} .:$ Glacial-interglacial Indian summer monsoon dynamics, science, 333, 719-723, 2011.

1230 Zhuang, G., Pagani, M., and Zhang, Y. G.: Monsoonal upwelling in the western Arabian Sea since the middle Miocene, Geology, 45, 655-658, 2017.

Ziegler, M., Lourens, L. J., Tuenter, E., Hilgen, F., Reichart, G. J., and Weber, N.: Precession phasing offset between Indian summer monsoon and Arabian Sea productivity linked to changes in Atlantic overturning circulation, Paleoceanography, 25, 2010.

1235 Zweng, M., Reagan, J., Antonov, J., Locarnini, R., Mishonov, A., Boyer, T., Garcia, H., Baranova, O., Johnson, D., and Seidov, D.: World Ocean Atlas 2013, Volume 2: Salinity, NOAA Atlas NESDIS, 74, 39, 2013. 

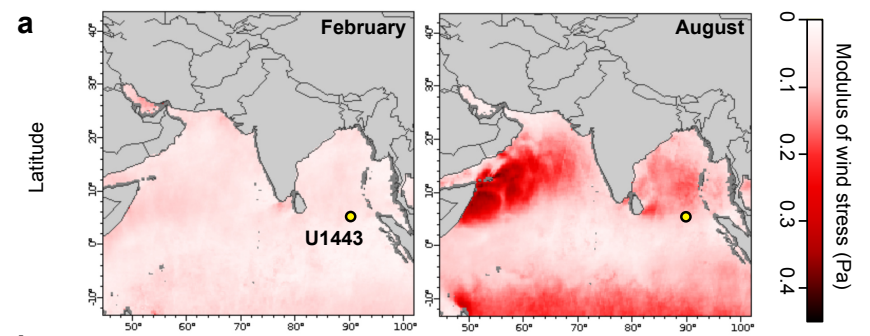

b
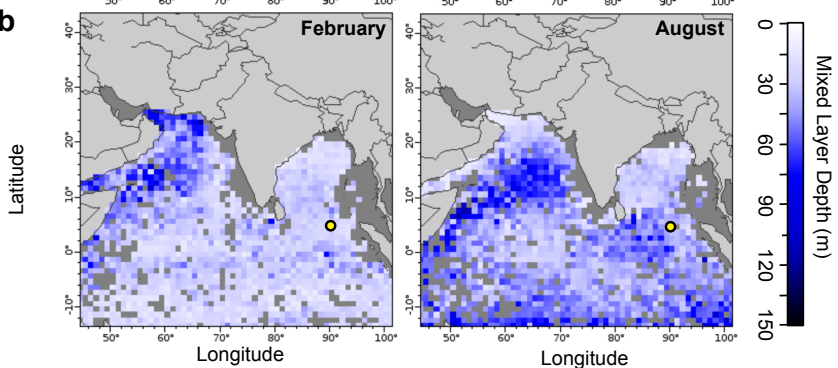

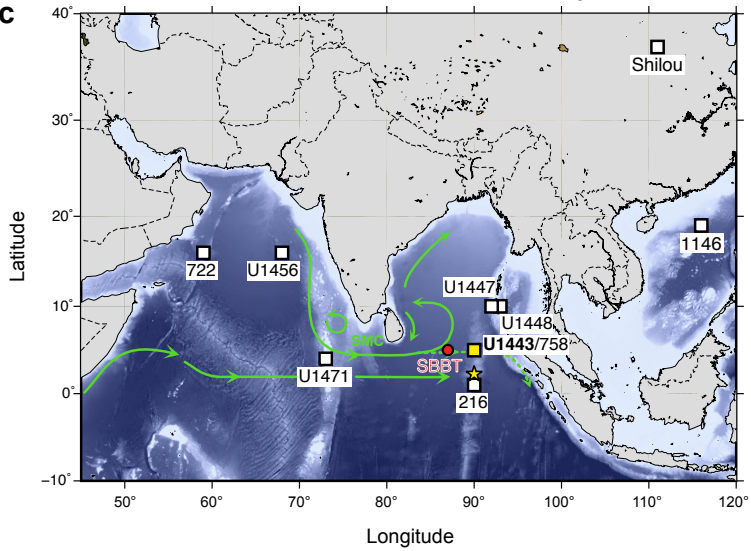

Figure 1: Seasonal contrast (February vs August) in wind stress (a) and mixed layer depth (b). Yellow dots indicate the modern location of IODP Site U1443. Maps were created on the ERDDAP website using the datasets Wind Stress, Metop-A ASCAT, 0.25', Global, Near Real Time, 2009present (Monthly) and Ocean Climatology Ocean Mixed Layer Depth MLD T02 kriging (see methods for details). $\mathbf{c}$ : Regional bathymetric map showing modern locations of marine and terrestrial sites discussed in this study (white squares) and the location of Site U1443, a redrill of Site 758, in the modern ocean (yellow square) and its paleolatitude at $10 \mathrm{Ma}$ (yellow star, $\sim 2^{\circ} \mathrm{N}$, data from paleolatitude.org). The red circle shows the location of the SBBT sediment trap. Green arrows show surface ocean circulation during the summer monsoon (July/August) and the eastward flow of waters from the Arabian Sea into the BOB via the Southwest Monsoon Current (SMC), after Schott et al. (2009). 

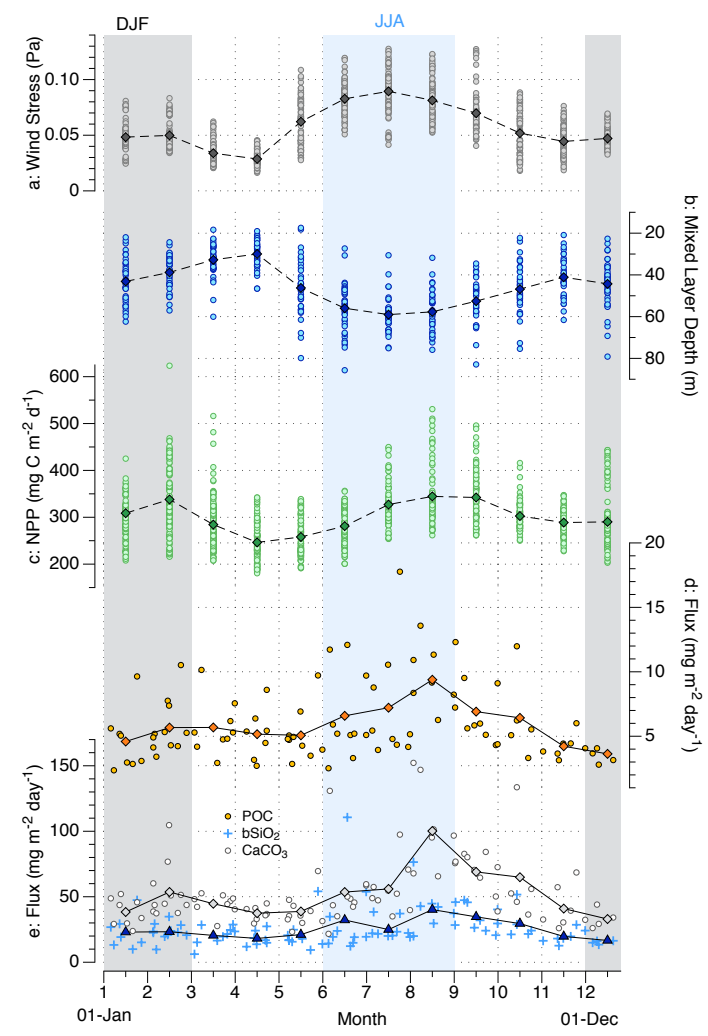

Figure 2: Modern, seasonal oceanographic variability above Site U1443 in the southern BOB. a: wind stress, b: mixed layer depth (MLD), c: net primary productivity (NPP), d: particulate organic carbon (POC) flux, e: biogenic silica (bSi) and calcium carbonate (CaCO3) flux. See Section 2.1 for details of individual datasets and sources. Points represent individual months, diamonds and triangles with lines represent monthly mean values over entire time series. Months ( $\mathrm{x}$-axis) run from $1\left(1^{\text {st }}\right.$ January $)$ to $12\left(1^{\text {st }}\right.$ December $) . J J A=$ June, July August, DJF = December, January, February. 


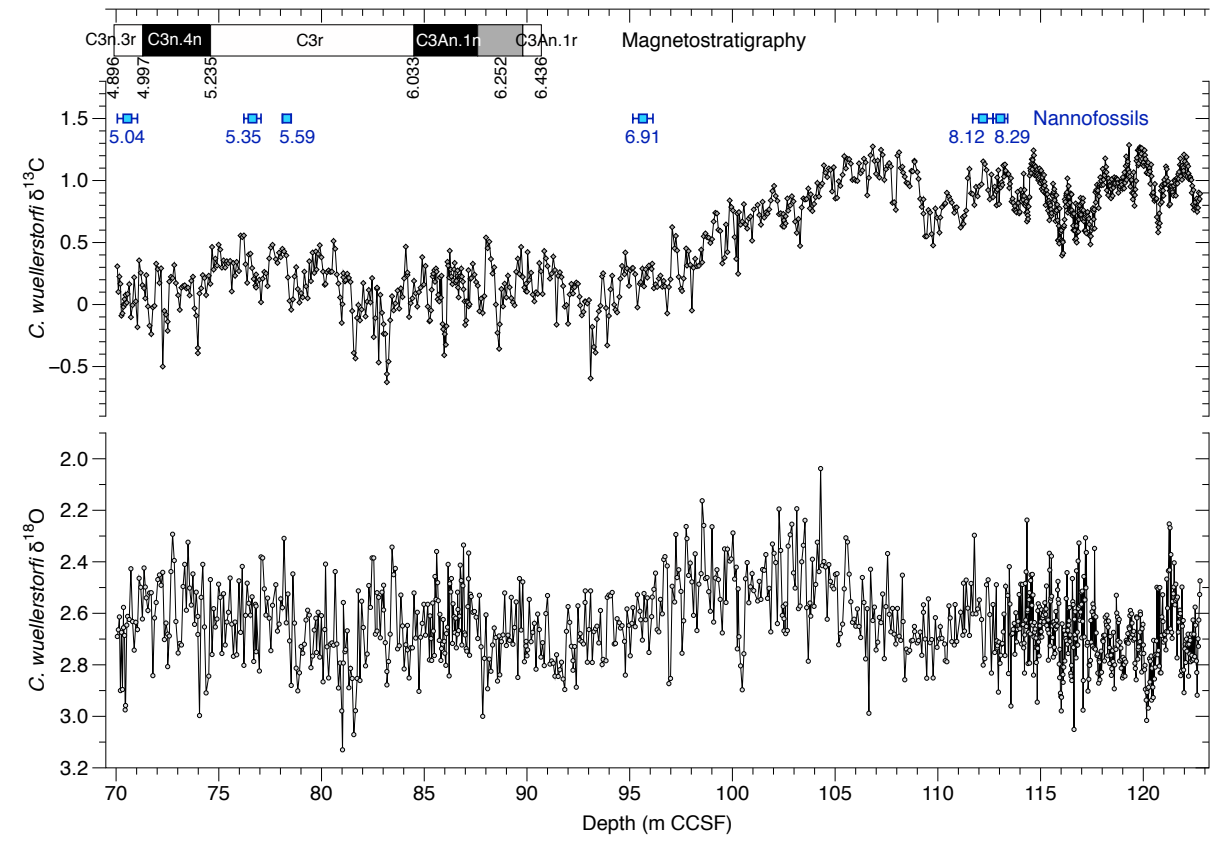

Figure 3: U1443 benthic foraminiferal (Cibicidoides wuellerstorfi) $\delta^{18} \mathrm{O}$ (bottom) and $\delta^{13} \mathrm{C}$ (top) data on the composite depth scale. Blue squares show refined depth ranges for calcareous nannofossil datums (see Table S1), and shipboard magnetostratigraphy is also shown for the interval over which it could be reliably determined. Between $\sim 90$ and $128 \mathrm{~m} \mathrm{CCSF}$, sediments in cores from all holes showed scattered directional signals during pass-through magnetic remanence measurement, which hindered any determination of polarity patterns in this interval across the whole site (Clemens et al., 2016). Black and white zones = normal and reversed polarity, respectively; grey zones = magnetic polarity not clearly determined. All numbers are age assignations for boundaries/nannofossil events in Ma (Gradstein et al., 2012). 


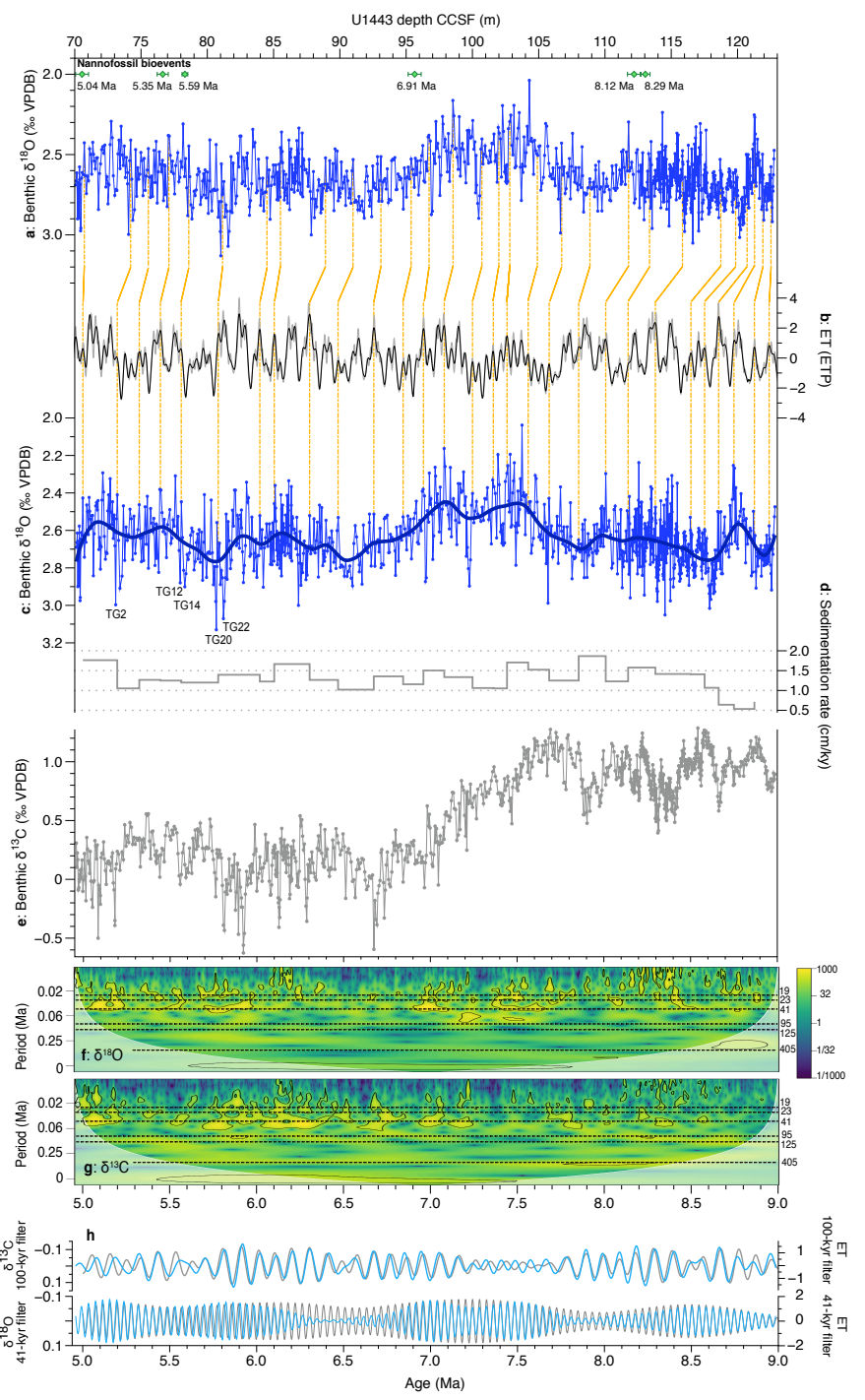

Figure 4: Astronomical (minimal) tuning of Site $\mathrm{U} 1443$ benthic $\delta^{18} \mathrm{O}$ record to ET target. a: benthic $\delta^{18} \mathrm{O}$ record on depth scale with nannofossil-based age constraints, $\mathbf{b}$ : ET tuning target (1:1 weighting, normalised). ETP (1:0.5:-0.4 weighting, normalised) is also shown in grey.

1280 Astronomical time series from (Laskar et al., 2004). c: tuned benthic $\delta^{18} \mathrm{O}$ vs age, d: sedimentation rates, e: tuned benthic $\delta^{13} \mathrm{C}$ vs age. Tie-points between $\mathbf{a}$ and $\mathbf{b}$ are shown in orange (see Table 1). An age-depth plot showing ET tie-points and good agreement with biostratigraphic age control is shown in Fig S1. f and g: wavelet analyses of tuned isotope records; white shaded area shows cone of influence and contours show 95\% significance level. Main orbital periods are shown on the right

1285 in kyr. h: Filtered tuned benthic isotope records compared to filtered ET (as in b). Top: 100-kyr filtered benthic $\delta^{13} \mathrm{C}$ (blue; Gaussian filter centred on $100 \mathrm{kyr}$ with bandwidth $\pm 25 \mathrm{kyr}$ to include 95 and $125 \mathrm{kyr}$ peaks) compared with filtered ET (grey, identical filter design). Bottom: 41-kyr filtered 
benthic $\delta^{18} \mathrm{O}$ (blue, Gaussian filter centred on $41.5 \mathrm{kyr}$ with bandwidth $\pm 1.5 \mathrm{kyr}$ ) compared with filtered ET (grey, identical filter design).

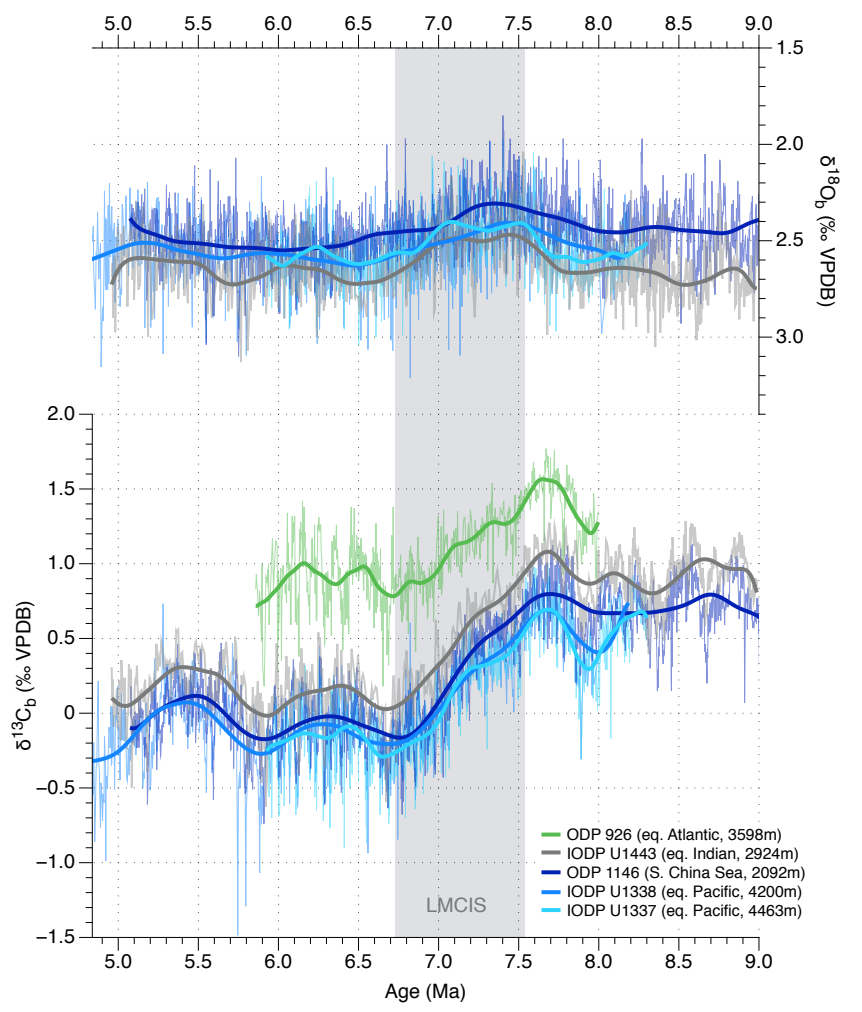

Figure 5: Late Miocene evolution of low-latitude deep-ocean inter-basin benthic $\delta^{13} \mathrm{C}$ and $\delta^{18} \mathrm{O}$ gradients. South China Sea ODP Site 1146 (Holbourn et al., 2018) with age model revised in (Holbourn et al., In Press), equatorial Pacific IODP Sites U1338 (Drury et al., 2018; Drury et al., 2016) and U1337 (Drury et al., 2017), and ODP Site 926 (Shackleton and Hall, 1997; Drury et al., 2017; Zeeden et al., 2013). All records are shown on their latest independent orbitally-tuned chronologies. We have excluded Caribbean ODP Site 999 from this figure because it is bathed in intermediate water masses due to basin geometry and sill depths (Bickert et al., 2004). Deep South

1300 Atlantic Site 704 (Müller et al., 1991) data are not plotted due to clear age model discrepancies when compared to orbitally-tuned records. All $\delta^{18} \mathrm{O}$ records are based on Cibicidoides wuellerstorfi or C. mundulus therefore no corrections are applied, following (Jöhnch et al., 2021). The Site 926 record includes $\delta^{13} \mathrm{C}$ corrections for some samples due to the multispecific nature of the record (Drury et al., 2017). No correction was applied to C. wuellerstorfi or C. mundulus $\delta^{13} \mathrm{C}$ values. 

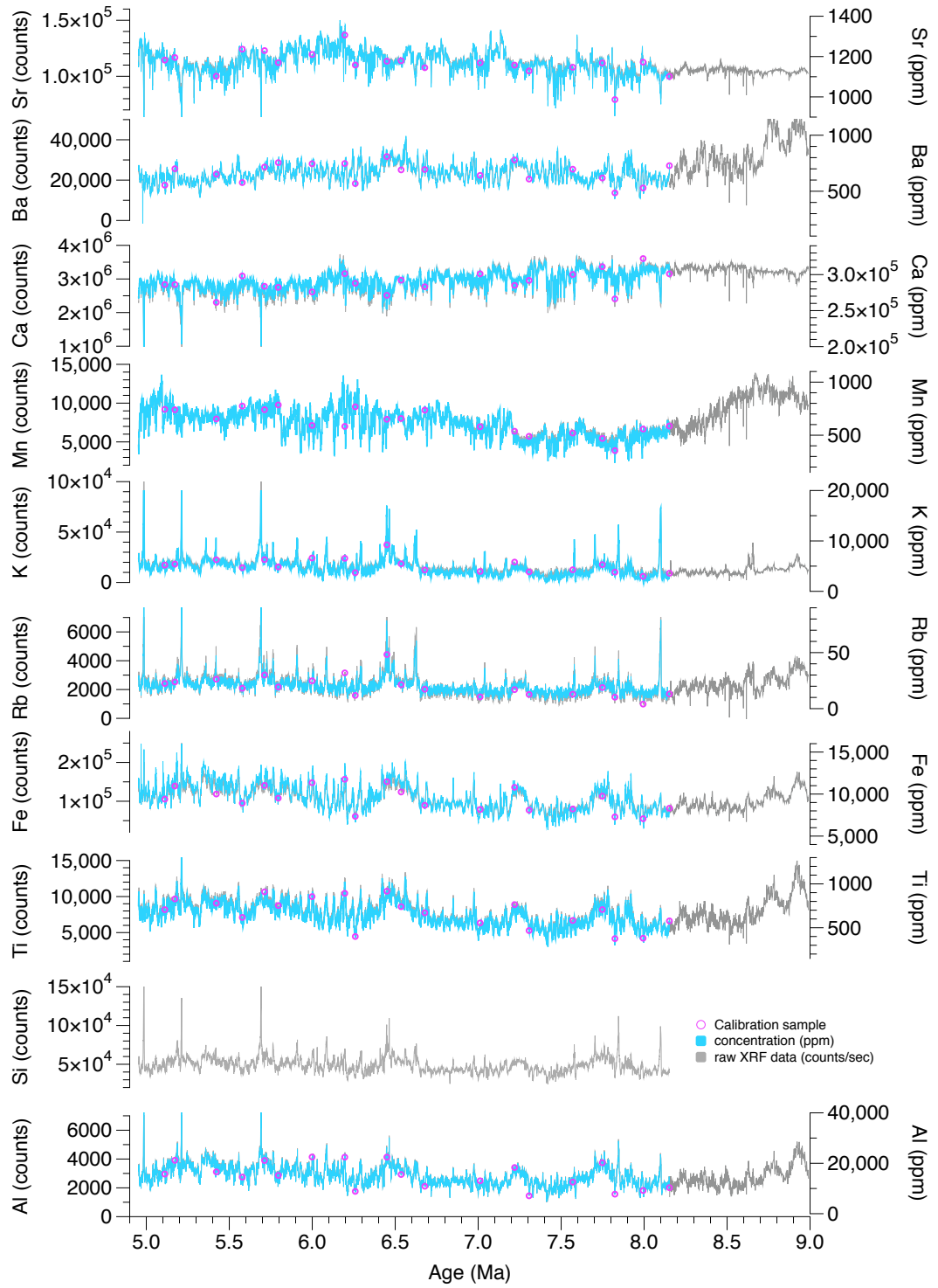

Figure 6: Raw counts/sec (grey lines) and calibrated concentration (blue lines) scanning XRF elemental data over the late Miocene interval. Pink circles show samples used for calibration (See Fig. S6). 


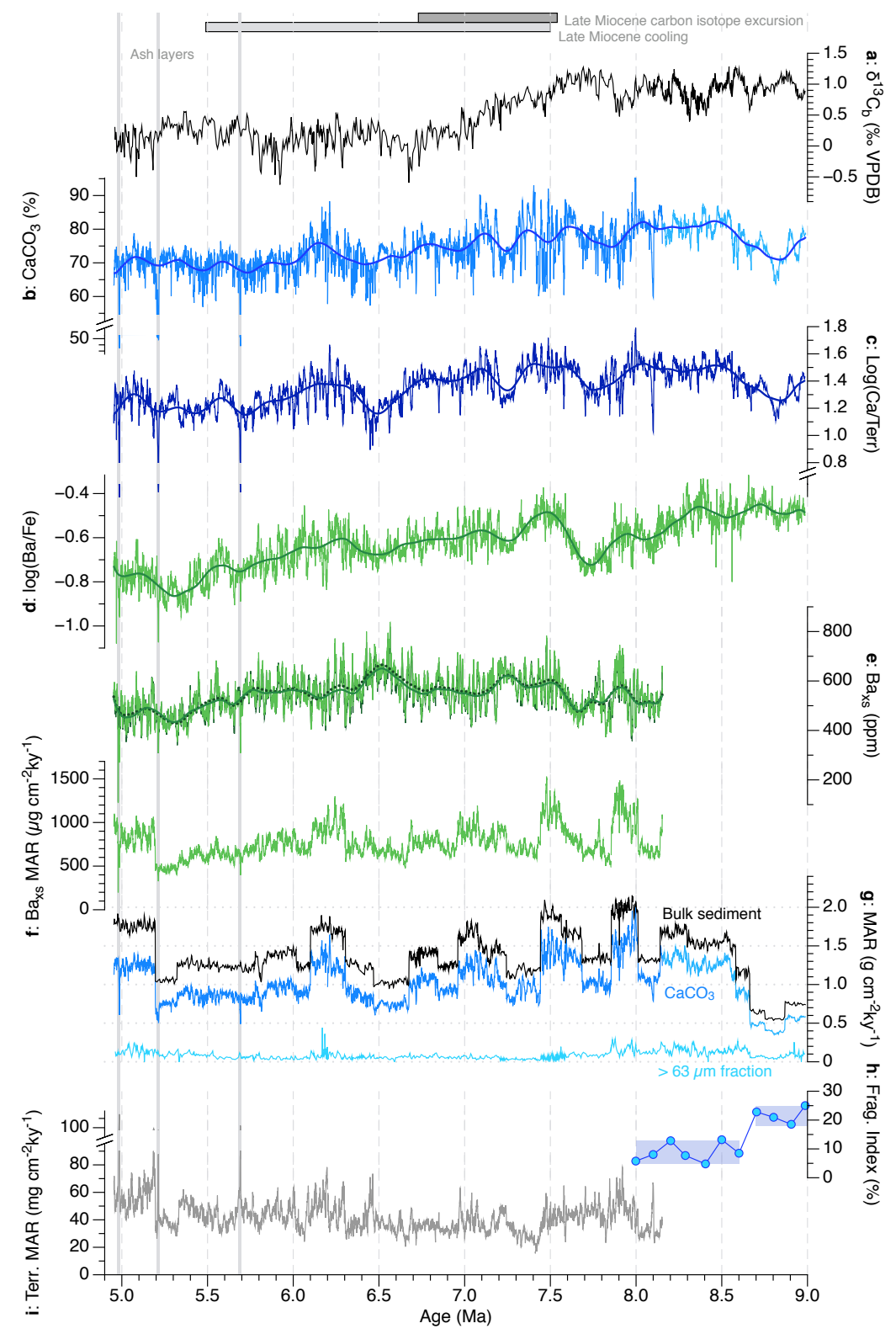

Figure 7: XRF-derived late Miocene $\mathrm{CaCO}_{3}$ and export productivity records from Site U1443. a: benthic $\delta^{13} \mathrm{C}$, b: percent $\mathrm{CaCO}_{3}$, c: $\log (\mathrm{Ca} / \mathrm{Terr}), \mathbf{d}: \log (\mathrm{Ba} / \mathrm{Fe}), \mathbf{e}: \mathrm{Ba}_{\mathrm{xs}}$ calculated with both [Al] (light green) and [Ti] (dark green), f: [Ba] $]_{x s} \mathrm{MAR}, \mathbf{g}$ : bulk (black), $\mathrm{CaCO}_{3}$ (blue), and $>63 \mu \mathrm{m}$ fraction (light blue) MAR, $\mathbf{h}$ : foraminiferal fragmentation index (following Le and Shackleton,

1315 1992), i: Terrigenous ( $\mathrm{Al}+\mathrm{Fe}+\mathrm{Ti}+\mathrm{K}+\mathrm{Rb}) \mathrm{MAR}$. For $\mathrm{CaCO}_{3}$ records, lighter blue lines are based on $\% \mathrm{CaCO}_{3}$ from Lübbers et al. (2019) and darker blue lines are based on $\% \mathrm{CaCO}_{3}$ estimates in this study. The late Miocene carbon isotope excursion and the main interval of late Miocene SST cooling are shown as grey bars. Shaded intervals are identified ash layers. 

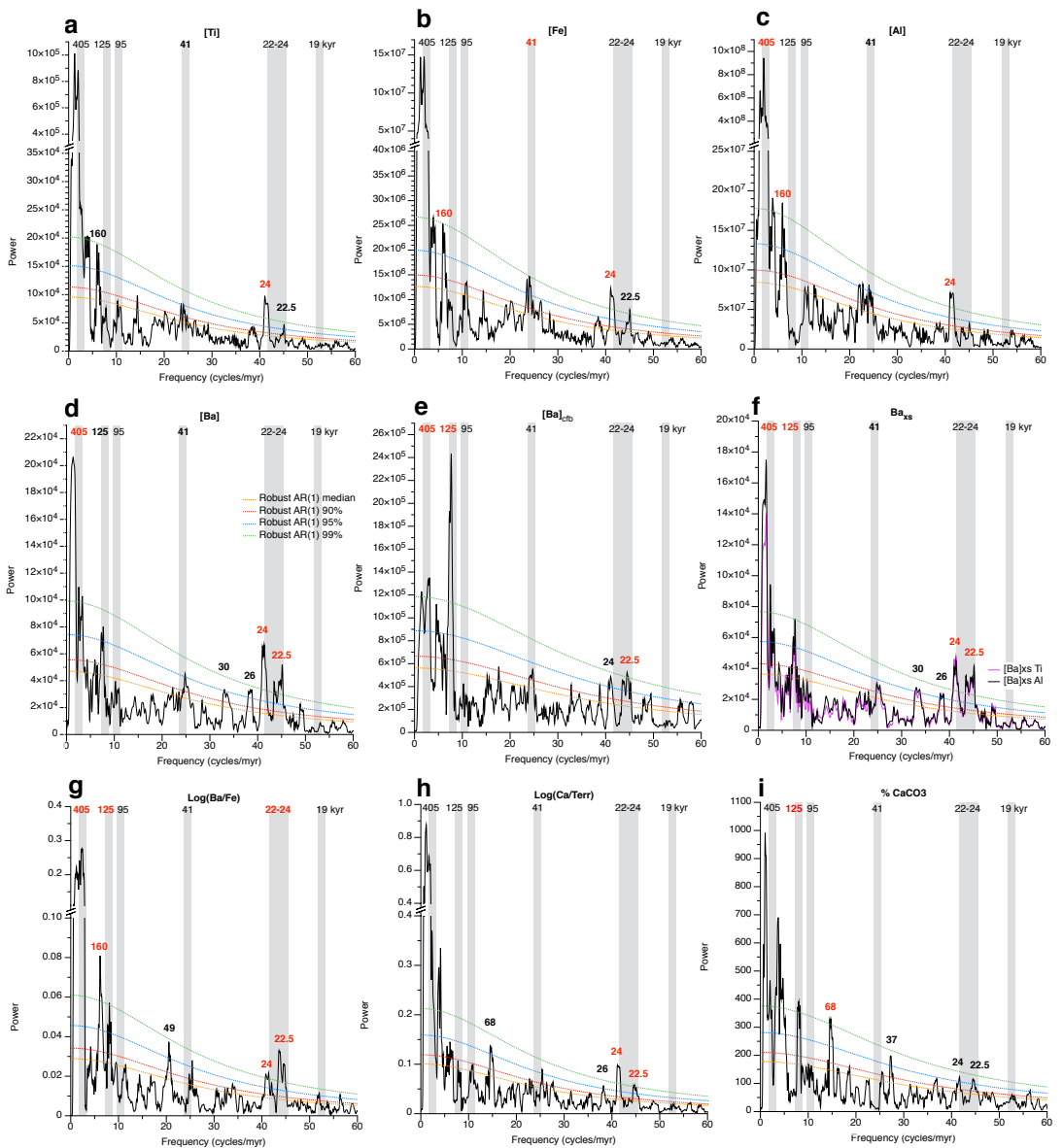

Figure 8: Spectral analyses for over the 9-5 Ma interval (log ratios and $\left.\% \mathrm{CaCO}_{3}\right)$ or $8.15-5 \mathrm{Ma}$ interval (calibrated element concentrations and $[\mathrm{Ba}]_{\mathrm{xs}}$ ). a: $[\mathrm{Ti}], \mathbf{b}:[\mathrm{Fe}], \mathbf{c}:[\mathrm{Al}], \mathbf{d}:[\mathrm{Ba}], \mathbf{e}:[\mathrm{Ba}]_{\mathrm{cfb}}$ (carbonate free basis), f: $[\mathrm{Ba}]_{\mathrm{xs}}, \mathbf{g :} \log (\mathrm{Ba} / \mathrm{Fe}), \mathbf{h}: \log (\mathrm{Ca} / \mathrm{Terr}), \mathbf{i}: \% \mathrm{CaCO}_{3}$. Grey bands denote primary orbital periods based on the La04 astronomical solution. The 22-24 kyr band covers two peaks centred at 23.5 and $22.3 \mathrm{kyr}$. 


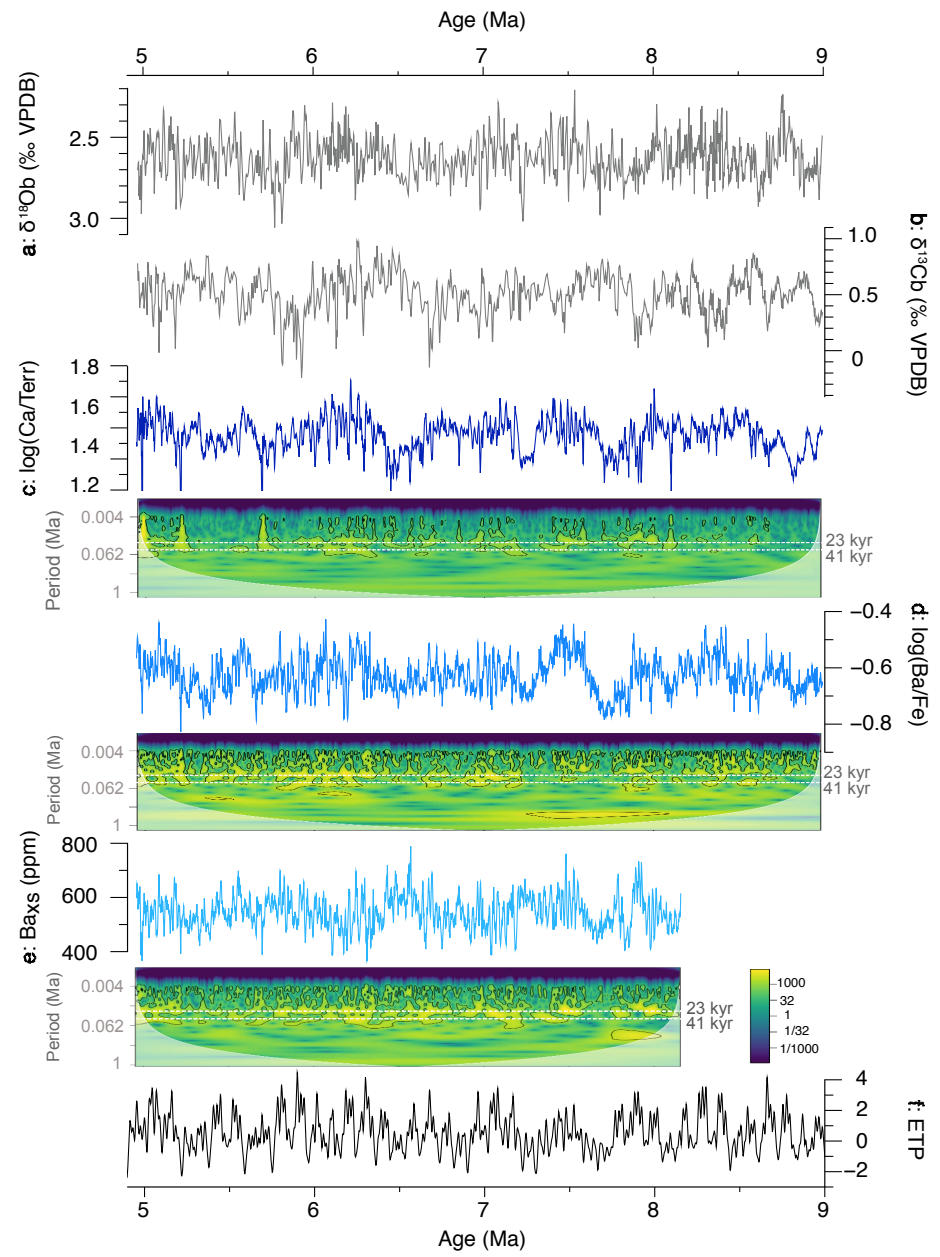

Figure 9: Orbital-scale variability of productivity and $\mathrm{CaCO}_{3}$ proxies at Site $\mathrm{U} 1443$. All records shown here are bandpassed as described in the methods. (a) benthic $\delta^{18} \mathrm{O}$, (b) benthic $\delta^{13} \mathrm{C}$, (c) $\log (\mathrm{Ca} / \mathrm{Terr}),(\mathrm{d}) \log (\mathrm{Ba} / \mathrm{Fe})$, (e) [Ba $]_{\mathrm{xs}}$, (f) ETP. For c-e, wavelet analyses are shown, illustrating dominant precession-scale (22-24 kyr) variability in Ba proxies and both precession and obliquity (41-kyr) variability in $\log (\mathrm{Ca} / \mathrm{Terr})$. 


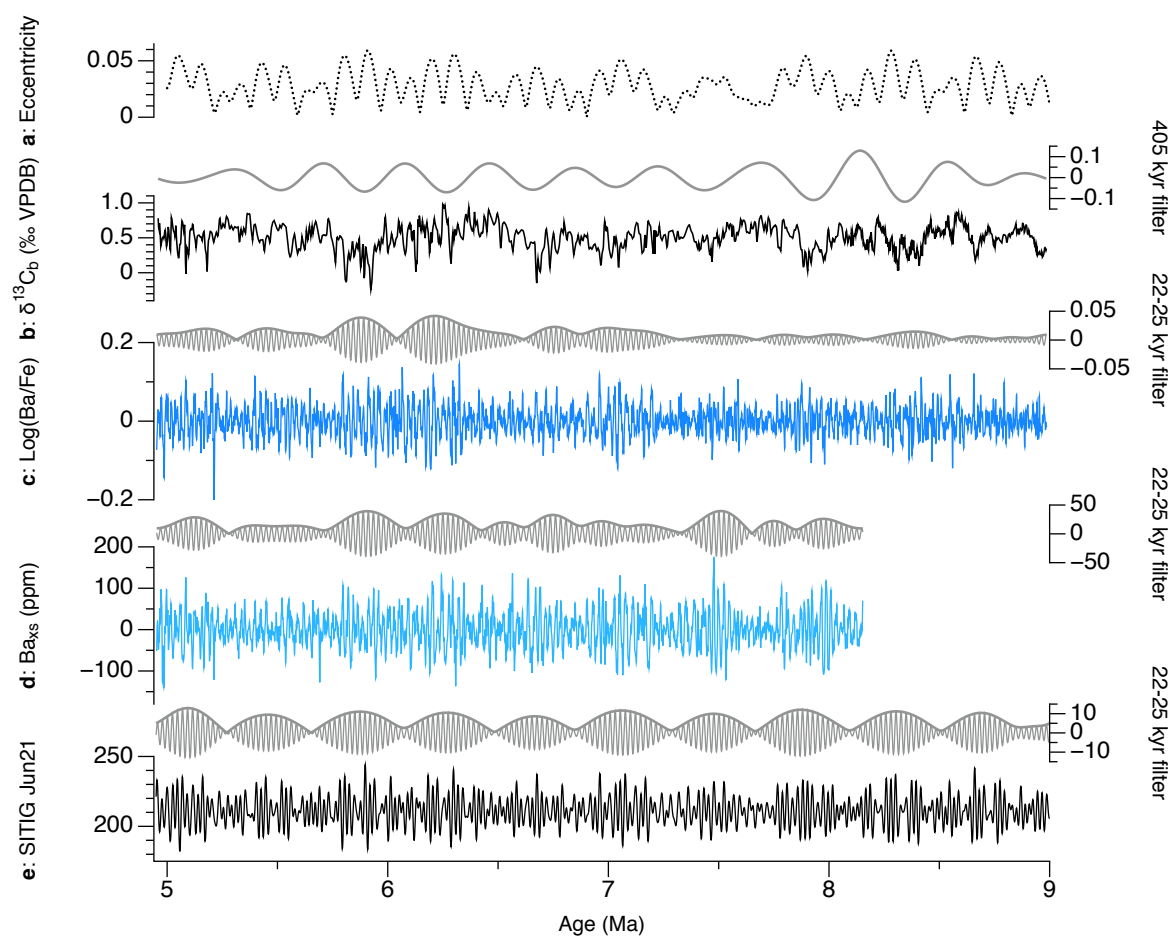

Figure 10: Detrended and filtered late Miocene U1443 records to illustrate precession-band variance and amplitude modulation. a: eccentricity (Laskar et al., 2004), b: benthic $\delta^{13} \mathrm{C}$ (bandpassed as in Fig. 9) and its 405-kyr filter (above) (note reversed y-axes). c: Lowess-detrended $\log (\mathrm{Ba} / \mathrm{Fe})$ (window $=0.1 \mathrm{Ma}$ ) and 22-25 kyr filter (above), $\mathbf{d}$ : Lowess-detrended $\mathrm{Ba}_{\mathrm{xs}}$ (window $=$ $0.1 \mathrm{Ma}$ ) and its 22-25 kyr filter (above), e: The summer inter-tropical insolation gradient (SITIG, calculated as the insolation difference between $23^{\circ} \mathrm{N}$ and $23^{\circ} \mathrm{S}$ on $21^{\text {st }}$ June using orbital solution of Laskar et al. (2004)) and its 22-25 kyr filter and amplitude modulation (above); For panels c-e, raw datasets were filtered using a Tanner-Hilbert filter centred on 43 cycles/myr with bandwidth \pm 3 1345 (designed to include both the $\sim 24 \mathrm{kyr}$ and $\sim 22 \mathrm{kyr}$ precession periods). For panel b, a TannerHilbert filter centred on 2.47 cycles/myr with bandwidth \pm 0.8 was applied. 

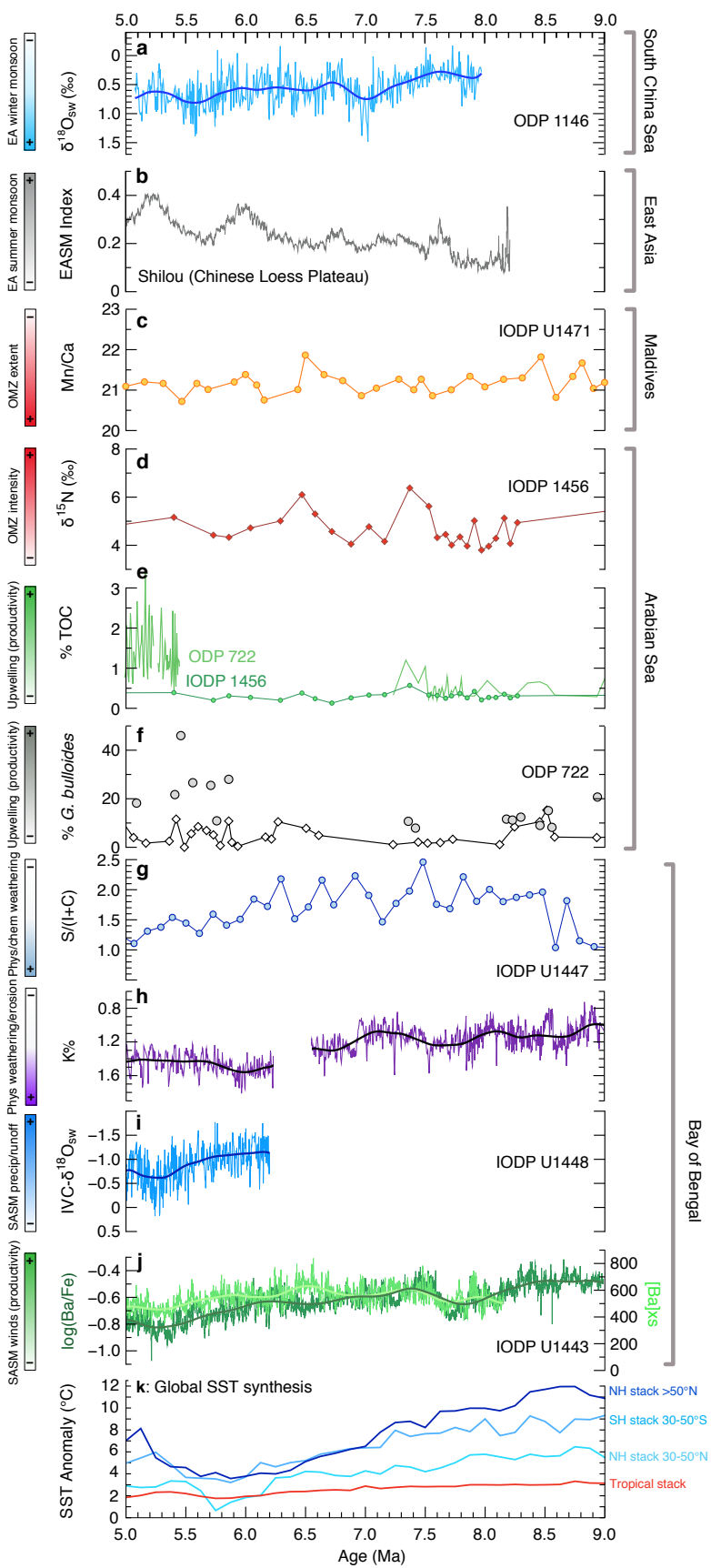

Figure 11: Compilation of late Miocene (9-5 Ma) Asian monsoon reconstructions, showing representative records from different regions and their published interpretations (bars on left). a: Seawater $\delta^{18} \mathrm{O}$ showing an increase in East Asian winter monsoon strength at $~ 7.4 \mathrm{Ma}$ (Holbourn et al., 2018; Holbourn et al., In Press), b: Stacked magnetic records of the East Asian summer 
monsoon from the Chinese Loess Plateau (Ao et al., 2016), c: Mn/Ca ratios used to trace oxygen minimum zone (OMZ) variations from Maldives Site IODP U1471 (Betzler et al., 2016), d: $\delta^{\natural} \mathrm{N}$

1355 record from Arabian Sea site IODP U1456 showing OMZ intensity (Tripathi et al., 2017), e: total organic carbon (TOC) \% from Arabian Sea sites IODP U1456 and ODP Site 722 (Huang et al., 2007; Tripathi et al., 2017),f: \% Gobigerinoides bulloides, a planktic foraminiferal upwelling indicator, at ODP Site 722 (Huang et al., 2007; Kroon et al., 1991), G. bulloides was counted in the $>150 \mu \mathrm{m}$ fraction in Huang et al. (white diamonds) and the $>125 \mu \mathrm{m}$ fraction in Kroon et al. (grey 1360 circles), g: clay mineralogy (smectite/(illite + chlorite)) at IODP Site U1447 in the Andaman Sea (Lee et al., 2020), h: Percentage Potassium (K\%) at IODP Site U1447 derived from spectral natural gamma ray measurements (Kuhnt et al., 2020), i: Andaman Sea IODP Site U1448 ice-volumecorrected seawater $\delta^{18} \mathrm{O}$ record (Jöhnck et al., 2020), and $\mathbf{j}$ : Export productivity records from Site U1443 (this study). k: Global sea surface temperature trends (expressed as anomalies relative to the 1365 present), stacked by latitude band (Herbert et al., 2016). All records are on their original age models, and Loess smooths are shown for high-resolution records. 